\title{
Which processes drive observed variations of HCHO columns over India?
}

\author{
Luke Surl $^{1,2}$, Paul I. Palmer ${ }^{1,2}$, and Gonzalo González Abad $^{3}$ \\ ${ }^{1}$ National Centre for Earth Observation, University of Edinburgh, Edinburgh, UK \\ ${ }^{2}$ School of GeoSciences, University of Edinburgh, Edinburgh, UK \\ ${ }^{3}$ Atomic and Molecular Physics Division, Harvard-Smithsonian Center for Astrophysics, Cambridge, Massachusetts, USA
}

Correspondence: Paul I. Palmer (paul.palmer@ed.ac.uk)

Received: 31 October 2017 - Discussion started: 22 November 2017

Revised: 20 February 2018 - Accepted: 8 March 2018 - Published: 5 April 2018

\begin{abstract}
We interpret HCHO column variations observed by the Ozone Monitoring Instrument (OMI), aboard the NASA Aura satellite, over India during 2014 using the GEOS-Chem atmospheric chemistry and transport model. We use a nested version of the model with a horizontal resolution of approximately $25 \mathrm{~km}$. HCHO columns are related to local emissions of volatile organic compounds (VOCs) with a spatial smearing that increases with the VOC lifetime. Over India, HCHO has biogenic, pyrogenic, and anthropogenic VOC sources. Using a 0-D photochemistry model, we find that isoprene has the largest molar yield of $\mathrm{HCHO}$ which is typically realized within a few hours. We also find that forested regions that neighbour major urban conurbations are exposed to high levels of nitrogen oxides. This results in depleted hydroxyl radical concentrations and a delay in the production of $\mathrm{HCHO}$ from isoprene oxidation. We find that propene is the only anthropogenic VOC emitted in major Indian cities that produces $\mathrm{HCHO}$ at a comparable (but slower) rate to isoprene. The GEOS-Chem model reproduces the broad-scale annual mean HCHO column distribution observed by OMI $(r=0.6)$, which is dominated by a distinctive meridional gradient in the northern half of the country, and by localized regions of high columns that coincide with forests. Major discrepancies are noted over the Indo-Gangetic Plain (IGP) and Delhi. We find that the model has more skill at reproducing observations during winter (JF) and pre-monsoon (MAM) months with Pearson correlations $r>0.5$ but with a positive model bias of $\simeq 1 \times 10^{15}$ molec $\mathrm{cm}^{-2}$. During the monsoon season (JJAS) we reproduce only a diffuse version of the observed meridional gradient $(r=0.4)$. We find that on a continental scale
\end{abstract}

most of the HCHO column seasonal cycle is explained by monthly variations in surface temperature $(r=0.9)$, suggesting a role for biogenic VOCs, in agreement with the 0-D and GEOS-Chem model calculations. We also find that the seasonal cycle during 2014 is not significantly different from the 2008 to 2015 mean seasonal variation. There are two main loci for biomass burning (the states of Punjab and Haryana, and northeastern India), which we find makes a significant contribution (up to $1 \times 10^{15}$ molec $\mathrm{cm}^{-2}$ ) to observed HCHO columns only during March and April over northeastern India. The slow production of $\mathrm{HCHO}$ from propene oxidation results in a smeared hotspot over Delhi that we resolve only on an annual mean timescale by using a temporal oversampling method. Using a linear regression model to relate GEOS-Chem isoprene emissions to HCHO columns we infer seasonal isoprene emissions over two key forest regions from the OMI HCHO column data. We find that the a posteriori emissions are typically lower than the a priori emissions, with a much stronger reduction of emissions during the monsoon season. We find that this reduction in emissions during monsoon months coincides with a large drop in satellite observations of leaf phenology that recovers in post monsoon months. This may signal a forest-scale response to monsoon conditions.

\section{Introduction}

Formaldehyde (HCHO) is an important source of the hydroperoxyl radical (Volkamer et al., 2010; Whalley et al., 2010), and a source of upper tropospheric hydroxyl radical 
(OH) (Jaeglé et al., 1998). It therefore plays a role in determining the oxidizing capacity of the global troposphere. The principal source of $\mathrm{HCHO}$ is the oxidation of methane $\left(\mathrm{CH}_{4}\right)$, which provides a global ambient background. Shorter-lived non-methane volatile organic compounds (NMVOCs) elevate $\mathrm{HCHO}$ concentrations over continental atmospheres. Minor direct $\mathrm{HCHO}$ sources include biomass burning, industry, agriculture, automobiles, shipping, and vegetation. The atmospheric lifetime of $\mathrm{HCHO}$, determined by $\mathrm{OH}$ and photolysis, is typically several hours. Building on our past studies (Palmer et al., 2003, 2006; Barkley et al., 2008; Gonzi et al., 2011), we interpret $\mathrm{HCHO}$ column distributions over India observed by the Ozone Monitoring Instrument (OMI) aboard the NASA Aura spacecraft (Levelt et al., 2006). We interpret spatial and temporal variations in terms of biogenic, pyrogenic, and anthropogenic VOC sources.

India has the sixth largest economy and the second largest population of any country. It also has one of the largest increases in mortality rates due to chronic exposure to elevated levels of surface ozone and particulate matter (Cohen et al., 2017). Figure 1 shows that India has a rich landscape that includes the Thar Desert over northwestern India, major forests over the southwestern coast and over the east and northeast, and five megacities (New Delhi, Mumbai, Kolkata, Bengaluru, and Chennai). The Indo-Gangetic Plain (IGP) stretches from eastern Pakistan, across the northern edge of India (bounded by the Himalayas), to Bangladesh. The IGP represents more than a quarter of a million acres of fertile land, which is used primarily to grow rice and wheat, but also maize, sugarcane, and cotton. The southwest monsoon represents the main source of water to the IGP, with contributions also from rivers flowing from the Himalayas. The southwest monsoon begins in June and subsides in September. High temperatures over the Thar Desert cause a region of low pressure that helps to establish a large-scale land/sea breeze with the Indian Ocean. This results in warm, moisture-laden air from the Indian Ocean travelling inland. Eventually, this air meets the Himalayas where it is forced to rise. As the air rises, cooler temperatures result in precipitation. Some areas of India receive $10 \mathrm{~m}$ of rain annually, mostly during the monsoon season.

Satellite columns observations of $\mathrm{HCHO}$ were originally developed using observed UV spectra from the Global Ozone Monitoring Experiment (Thomas et al., 1998; Chance et al., 2000). HCHO column data are now available from a range of satellite instruments, but here we focus on data from OMI. Generally, slant $\mathrm{HCHO}$ columns are retrieved by directly fitting to observed spectra in a narrow UV window (Chance et al., 2000; De Smedt et al., 2008; González Abad et al., 2015). Vertical columns are determined by scaling these slant columns by scene-dependent air mass factors (AMFs), taking clouds and aerosol scattering into account (Palmer et al., 2001). Past work has shown that HCHO columns over India have increased nationwide on average between $1.6 \% \mathrm{yr}^{-1}$ (1997-2009, De Smedt et al., 2010) and $1.5 \% \mathrm{yr}^{-1}$ (1995-
2013, Mahajan et al., 2015). Mahajan et al. (2015) also showed using coincident satellite measurements of HCHO and $\mathrm{NO}_{2}$ that over much of India $\mathrm{O}_{3}$ production is limited by the availability of nitrogen oxides but over urban regions it is limited by the availability of VOCs, supported by detailed modelling studies over Delhi (Sharma et al., 2016). Here, we employ a high-resolution $(\simeq 25 \mathrm{~km})$ model of atmospheric chemistry that is closely aligned with the resolution of the satellite data, allowing us to take advantage of the richness of these data.

$\mathrm{HCHO}$ columns are related to their parent VOC emissions with a smearing spatial scale that is related to the production rate and molar yield of $\mathrm{HCHO}$ (Palmer et al., 2003). Past studies have used this relationship to infer isoprene emissions from major forests (Palmer et al., 2003; Abbot et al., 2003; Shim et al., 2005; Palmer et al., 2006, 2007; Barkley et al., 2008; Millet et al., 2008; Stavrakou et al., 2009; Curci et al., 2010; Marais et al., 2012; Barkley et al., 2013), biomass burning emissions (Young and Paton-Walsh, 2010; Gonzi et al., 2011; Stavrakou et al., 2016), and anthropogenic emissions (Fu et al., 2007; Stavrakou et al., 2009). Detailed photochemical calculations that link VOCs and the time-dependent production of $\mathrm{HCHO}$ lay the groundwork for interpreting the HCHO column data. Many past studies have inferred VOC emissions from the $\mathrm{HCHO}$ columns using a linear regression model between these two variables (e.g. Palmer et al., 2003; Millet et al., 2008), but others have adopted a more rigorous Bayesian inverse model approach (e.g. Shim et al., 2005). For central Africa, Marais et al. (2012) employed an inversion method that accounted for the $\mathrm{NO}_{x}$ dependence of the isoprene-HCHO relationship. Given the large uncertainties associated with VOC emissions (e.g. Guenther et al., 2012) and the production of $\mathrm{HCHO}$ in the low- $\mathrm{NO}_{x}$ regime (Wolfe et al., 2016) both approaches provide useful insights. Our study is focused on India where there are significant sources of biogenic, pyrogenic, and anthropogenic VOCs.

The next section describes the OMI HCHO column data, the detailed box model used to study the time-dependent production of HCHO from VOC oxidation, and the GEOSChem atmospheric chemistry transport model focused on India. Section 3 reports the results from our analysis of the OMI HCHO column data over India, the associated model interpretation of these data, and the isoprene emissions we infer from the HCHO column data collected over two major forest regions. We conclude in Sect. 4.

\section{Data and methods}

Our data are focused on India, as defined by the GADM database of Global Administrative Areas (www.gadm.org). We adopt climatological definitions of seasons from the Indian Meteorological Department that are determined by the onset of the regional monsoon system as follows: winter includes January and February, the pre-monsoon season is 
(a)

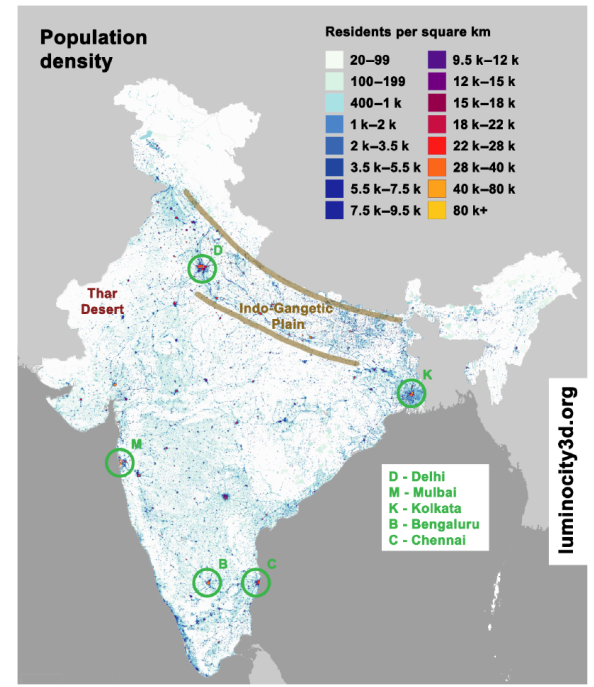

(c)

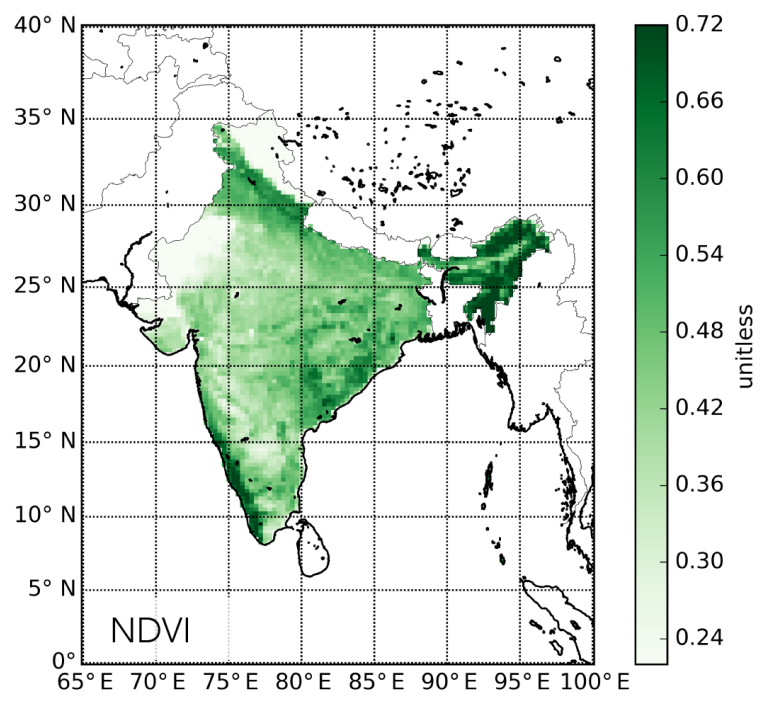

(b)

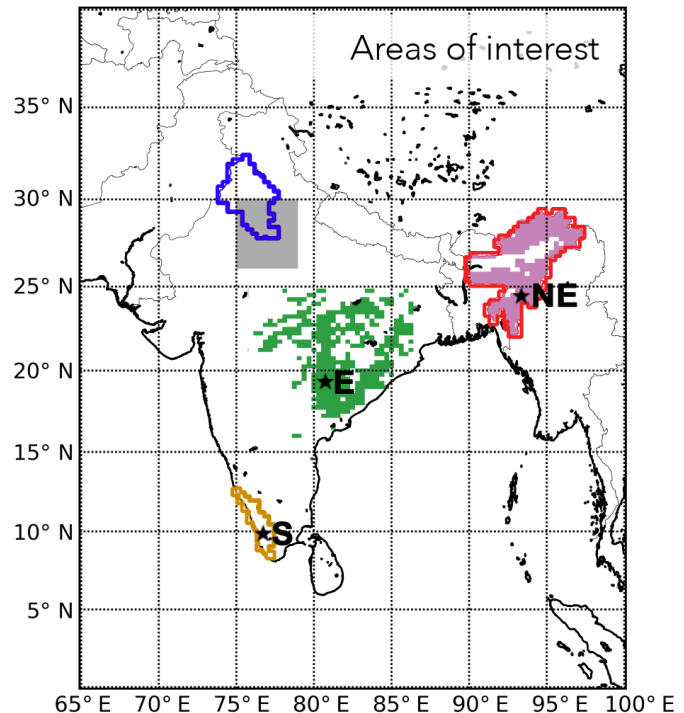


13:38, achieving daily global coverage subject to cloud coverage.

OMI uses two imaging grating spectrometers each with a CCD detector to collect solar backscattered radiation in the spectral range 270-500 nm using three channels: UV-1 (264$311 \mathrm{~nm}), \mathrm{UV}-2(307-383 \mathrm{~nm})$, and Vis $(349-504 \mathrm{~nm})$. OMI has an across-track swath width of $2600 \mathrm{~km}$, which in global mode is described by 60 scenes that have ground footprints from $13 \times 24 \mathrm{~km}^{2}$ at nadir to $28 \times 160 \mathrm{~km}^{2}$ at the swath edges.

Determination of HCHO vertical columns is a two-step procedure, which we describe below. First, slant columns are retrieved from the observed spectra. Second, an air mass factor (AMF) is used to transform these slant columns into geophysical vertical columns that can be compared more easily with models.

We use the NASA OMHCHOv003 data product (González Abad et al., 2015) from the NASA Data and Information Services Center, which fits HCHO slant columns in the $328.5-356.5 \mathrm{~nm}$ window and accounts for competing absorbers, the Ring effect, and undersampling. Typical slant columns range from $4 \times 10^{15}$ to $6 \times 10^{16}$ molec $\mathrm{cm}^{-2}$ with associated fitting uncertainties ranging from $30 \%$ for larger columns to more than $100 \%$ for smaller columns (González Abad et al., 2015).

We adopt a conservative approach to filtering data, based on previous studies (e.g. De Smedt et al., 2015). We filter slant column data using the main data quality flag (removing suspect, bad, or missing scenes); scenes that have been flagged as being affected by the row anomaly corresponding to a problem with a row of CCD detectors on OMI; scenes with slant column values greater than $15 \times 10^{16}$ molec cm$^{-2}$ that we also attribute to potential row anomalies; scenes with solar zenith angles less than $0^{\circ}$ or greater than $70^{\circ}$; scenes with cloud fractions $>0.4$; and scenes from the last two rows at the edge of the swath, which we believe are too wide to be useful in our analysis. We do not anticipate that these data filters will introduce bias in our analysis, with the exception of removing cloudy scenes that introduces a clear-sky bias. To evaluate the clear-sky bias, we compared the corresponding model HCHO columns (described below) with and without these cloudy scenes and find that removing them results in a monthly mean positive bias of $13 \%$, consistent with previous work (Palmer et al., 2001).

To transform each observed slant column to a vertical column we calculate an AMF that accounts for temporal and spatial variations from scattering due to clouds and aerosols, and for the vertical distribution of HCHO. This approach is described in detail by Palmer et al. (2001) and Martin et al. (2003), and has since been evaluated in a large number of studies (e.g. Palmer et al., 2003, 2006; Fu et al., 2007; Millet et al., 2008; Barkley et al., 2008; Curci et al., 2010; Gonzi et al., 2011; Marais et al., 2012). We use the OMI OMCLD02 cloud data product, and the nested GEOS-Chem model to provide information about aerosols and HCHO vertical distributions, described below.
Finally, as a post-processing step, we remove any largescale biases using a reference sector normalization procedure (Palmer et al., 2003; Martin et al., 2003). Over the remote Pacific we expect observed HCHO columns to be determined exclusively by the oxidation of methane. By anchoring observed values over this specific region $\left(0-40^{\circ} \mathrm{N}\right.$, $160-180^{\circ} \mathrm{W}$ ) to the corresponding GEOS-Chem model values we determine the monthly bias that we subsequently subtract from the data within the study domain.

Previous work using aircraft observations over southeastern U.S. has reported that the OMHCHOv0003 OMI HCHO column data product has a negative bias (37\%), and that the GEOS-Chem model (v9-02) has a $10 \%$ negative bias (Zhu et al., 2016). In the absence of similar data over India, we cannot determine with certainty the generality of these biases, and have chosen to implicitly assume that the OMI data are not significantly impacted by systematic error.

\subsection{Models of tropospheric chemistry}

We use the CAABA box model, including a comprehensive description of atmospheric chemistry, to understand the time-dependent yield of HCHO from the oxidation of VOCs in Indian forest and urban environments. These calculations help determine which VOC emissions are responsible for observed HCHO column variations. We also use a nested version of the GEOS-Chem 3-D atmospheric chemistry model to interpret the satellite data and to understand chemistry on a regional spatial scale. We use this model to establish a relationship between emissions of VOCs and HCHO columns which is then used to infer emissions of VOCs that correspond to observed HCHO columns.

The chemical mechanisms from the CAABA box model and the GEOS-Chem model are not identical. CAABA includes a more explicit chemical mechanism and a reduced version of the Mainz Isoprene Mechanism 2 (MIM2, Taraborrelli et al., 2009). The version of GEOS-Chem we use here is described by Eastham et al. (2014). The latest version of the GEOS-Chem chemical mechanism, released after the majority of our calculations had been completed, results in an increase of the $\mathrm{HCHO}$ yield from the oxidation of isoprene. We find using preliminary calculations with v11-01 that the revised mechanism does not systematically change the results shown here. Previous studies have evaluated the performance of GEOS-Chem (Marvin et al., 2017) and MIM2 (Taraborrelli et al., 2009) against the Master Chemical Mechanism. The GEOS-Chem v10-01 mechanism slightly underestimates $\mathrm{HCHO}$ production in high- $\mathrm{NO}_{x}$ conditions and the MIM2 mechanism shows similar HCHO production across a wide range of $\mathrm{NO}_{x}$ values.

\subsubsection{Box modelling}

We use v3.0 of the CAABA/MECCA (0-D) box model (Sander et al., 2011), but without halogen, sulphur, and mer- 
cury chemistry, to estimate the time-dependent production of $\mathrm{HCHO}$ from the chemical oxidation of different VOCs in forest and urban photochemical environments (Table 1).

We set up the model to describe a well-mixed summertime boundary layer, with photochemistry driven by a diurnal cycle in sunlight. For each environment, the photolysis model JVAL (Sander et al., 2014) is used to calculate photolysis rates assuming clear-sky conditions given latitude, longitude, and day of year. For each study location, we assume constant values for humidity, pressure, temperature, and boundary layer height, taken from colocated GEOS-FP meteorology (see below). For forested environments we also prescribe fixed mixing ratios of $\mathrm{O}_{3}, \mathrm{NO}_{2}$, and $\mathrm{CO}$ from the GEOSChem model, described below. For the Delhi urban environment we use daytime average surface air pollutant values in 2014 as reported by (Tyagi et al., 2016): $\mathrm{O}_{3}$ (37 ppbv), $\mathrm{CO}$ (2.3 ppmv), and $\mathrm{NO}_{2}$ (19 ppbv), (Table 1). Figure 1 shows the three forested regions (denoted by E, NE, and S) we chose to explore the range of photochemical environments. For each calculation, we spun-up the model from initial conditions for $48 \mathrm{~h}$ before running the model for a further seven days. We use a model time step of two minutes.

To evaluate the time-dependent HCHO yield of anthropogenic and biogenic VOCs we run paired calculations as follows: (1) a control run; and (2) a run in which we perturb a VOC by approximately $5 \times 10^{14}$ molec $\mathrm{cm}^{-2}$ over a $15 \mathrm{~min}$ period at 09:00 LT on the first day after the two-day spin-up period. The perturbed amount is sufficiently small that we can assume that the chemistry response is approximately linear so that we can compare the perturbed run with the control run. We can then use control minus perturbed model calculations to determine $\mathrm{HCHO}$ per-carbon yield from the oxidation of the perturbed VOC.

\subsubsection{GEOS-Chem 3-D modelling}

We use v10-01 of the GEOS-Chem global model of atmospheric chemistry and transport (www.geos-chem.org), driven by GEOS-FP analysed meteorological fields, provided by the Global Modeling and Assimilation Office (GMAO) at NASA Goddard Space Flight Center. The native spatial resolution of these data is $0.25^{\circ}$ (latitude) $\times 0.3125^{\circ}$ (longitude), and includes 47 vertical terrain-following sigma-levels that describe the atmosphere from the surface to $0.01 \mathrm{hPa}$ of which about 30 are typically below the dynamic tropopause. The 3-D meteorological data are updated hourly, and 2-D fields and surface fields are updated every $3 \mathrm{~h}$. The chemical mechanism used is the "tropchem" mechanism (Eastham et al., 2014). The atmospheric chemistry and transport time steps are five and ten minutes, respectively.

We use the nesting capability of the model to focus on India, defined here as $0-40^{\circ} \mathrm{N}, 65-100^{\circ} \mathrm{E}$, using the native resolution of the meteorological data. We use time-dependent lateral boundary conditions archived from a self-consistent, $4^{\circ} \times 5^{\circ}$ version of the global full-chemistry model, which is
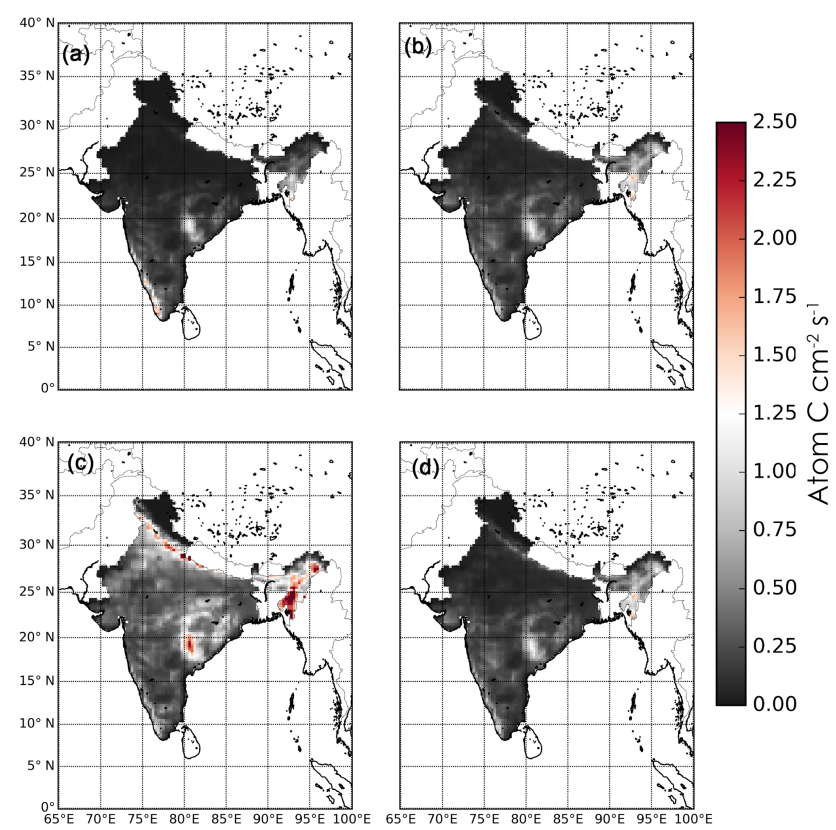

Figure 2. Seasonal isoprene emission rates (atom $\mathrm{Ccm}^{-2} \mathrm{~s}^{-1}$ ) from the MEGAN inventory (Guenther et al., 2012). Data are described on the GEOS-Chem $0.25^{\circ} \times 0.3125^{\circ}$ grid for (a) winter (JF), (b) pre-monsoon (MAM), (c) monsoon (JJAS), and (d) postmonsoon seasons (OND).

initialized in January 2013 to minimize the influence of initial conditions. Here, we describe emission inventories relevant to our nested India simulation and direct the reader to the GEOS-Chem website (http://geos-chem.org) for a more comprehensive description of inventories.

Monthly anthropogenic emissions for India are taken from the mosaic MIX inventory ( $\mathrm{Li}$ et al., 2017), including NO, $\mathrm{CO}, \mathrm{SO}_{2}$, and NMVOCs that are available on a spatial resolution of $0.25 \times 0.25^{\circ}$. The emissions for India are a mosaic of regional emission inventories, including the Regional Emission inventory in ASia (REAS) (Kurokawa et al., 2013) and those developed by the Argonne National Laboratory (Lu et al., 2011; Lu and Streets, 2012). Indian NMVOC emissions represent by mass $17 \mathrm{Tg}$ per year, of which $43 \%$ is from the residential sector, $36 \%$ is from transport, $20 \%$ is from industry, and a small amount is attributed to the power sector.

Approximately $20 \%$ of India's geographical area is described as forest. To describe biogenic VOC emissions of isoprene, monoterpenes, alkenes, and acetone we use the MEGAN v2.1 emission model (Model of Emissions of Gases and Aerosols from Nature, Guenther et al., 2012). Figure 2 shows seasonal isoprene emissions over India. Monoterpenes emission have a similar distribution to isoprene but are a factor of five smaller in magnitude. Given their relatively small influence on HCHO column variability (Palmer et al., 2003) we do not discuss them further. Within GEOS-Chem, we ad- 
Table 1. Photochemical and meteorological scenarios used for box model calculations. The emboldened letters E, NE, S denote the forested regions (Fig. 1), and D denotes Delhi. Ground-level temperature ( $T$ ), relative humidity (RH), boundary layer height (BLH) and mixing ratios are GEOS-Chem monthly mean values from each location.

\begin{tabular}{|c|c|c|c|c|c|c|c|c|}
\hline \multirow{2}{*}{ Scenario name } & \multirow{2}{*}{ Geographic location } & \multirow{2}{*}{ Month } & \multirow{2}{*}{$\begin{array}{r}\mathrm{T} \\
{[\mathrm{K}]}\end{array}$} & \multirow{2}{*}{$\begin{array}{l}\mathrm{RH} \\
{[\%]}\end{array}$} & \multirow{2}{*}{$\begin{array}{r}\text { BLH } \\
{[\mathrm{m}]}\end{array}$} & \multicolumn{3}{|c|}{ Fixed mixing ratio [ppbv] } \\
\hline & & & & & & $\mathrm{O}_{3}$ & $\mathrm{CO}$ & $\mathrm{NO}_{2}$ \\
\hline E01 & \multirow{4}{*}{$19.3^{\circ} \mathrm{N}, 80.6^{\circ} \mathrm{E}$} & Jan & 295 & 56 & 1240 & 49 & 232 & 1.1 \\
\hline E05 & & May & 307 & 33 & 1873 & 63 & 131 & 2.4 \\
\hline E08 & & Aug & 299 & 84 & 685 & 39 & 114 & 1.3 \\
\hline E11 & & Nov & 304 & 64 & 611 & 49 & 220 & 0.8 \\
\hline NE01 & \multirow{4}{*}{$24.4^{\circ} \mathrm{N}, 93.1^{\circ} \mathrm{E}$} & Jan & 292 & 65 & 648 & 42 & 277 & 1.8 \\
\hline NE05 & & May & 302 & 59 & 1202 & 55 & 154 & 0.8 \\
\hline NE08 & & Aug & 299 & 88 & 666 & 24 & 127 & 1.3 \\
\hline NE11 & & Nov & 296 & 73 & 925 & 43 & 241 & 1.4 \\
\hline S01 & \multirow{4}{*}{$9.8^{\circ} \mathrm{N}, 76.6^{\circ} \mathrm{E}$} & Jan & 300 & 59 & 1090 & 48 & 260 & 8.9 \\
\hline S05 & & May & 301 & 78 & 725 & 32 & 146 & 8.6 \\
\hline S08 & & Aug & 299 & 84 & 690 & 18 & 122 & 8.1 \\
\hline $\mathrm{S} 11$ & & Nov & 299 & 77 & 732 & 45 & 274 & 8.9 \\
\hline D05 & $28.61^{\circ} \mathrm{N}, 77.23^{\circ} \mathrm{E}$ & May & 307 & 18 & 1975 & 37 & 2300 & 19 \\
\hline
\end{tabular}

just the MEGAN model with time-dependent local environment conditions (e.g. surface temperature, photosynthetic active radiation, and leaf area index (LAI) from MODIS).

Monthly pyrogenic emissions are taken from the Global Fire Emissions Database (GFED) version 4 (van der Werf et al., 2017), which are available with a spatial resolution of $0.25 \times 0.25^{\circ}$.

To interpret OMI HCHO column data we sample the model at the local time averaged between 13:00 and 15:00, corresponding to the overpass time of OMI, and the location of each observed scene. To put 2014 into a broader temporal context, we interpreted OMI HCHO columns for years 2008-2015. We find that the AMF plays only a minor role in determining OMI vertical column variations so we do not expect our approach to significantly influence our study of variations in the $\mathrm{HCHO}$ columns.

\section{Results}

First, we report results from the box model calculation to provide some insights into the VOCs that determine the observed $\mathrm{HCHO}$ column variations. We then report the annual and seasonal spatial distributions of OMI and GEOS-Chem $\mathrm{HCHO}$ columns. Using correlative space-borne data we explore the role of biogenic, pyrogenic, and anthropogenic emissions in determining the spatial distributions of HCHO. Finally, using a model relationship between isoprene emissions and $\mathrm{HCHO}$ columns we infer isoprene emissions that are consistent with the OMI vertical columns.

\subsection{HCHO yield from VOC oxidation in urban and forest environments}

We use the CAABA/MECCA box model to determine the time-dependent production of $\mathrm{HCHO}$ from the VOCs that we expect to be emitted from urban and forest environments over India. This represents important groundwork for interpreting the satellite observations of HCHO. Table 1 provides an overview of the box model calculations we describe below.

Relating HCHO column variations to emissions of its parent VOC requires that the VOC (1) has a high yield of $\mathrm{HCHO}$ so that eventual concentrations are elevated above the global background, determined mainly by the oxidation of $\mathrm{CH}_{4}$; and (2) produces $\mathrm{HCHO}$ rapidly so that most of the $\mathrm{HCHO}$ is produced close to the emission source and not smeared over long spatial scales. Isoprene is the dominant $\mathrm{HCHO}$ precursor over many northern midlatitude and tropical forest ecosystems (Palmer et al., 2003, 2006; Barkley et al., 2008; Curci et al., 2010). Over tropical latitudes biomass burning emissions of VOCs also play a role in HCHO column variations (Fu et al., 2007; Barkley et al., 2008; Gonzi et al., 2011; Marais et al., 2012). Fu et al. (2007) also showed that reactive anthropogenic VOCs played a role in HCHO column variations over China.

\subsubsection{Biogenic VOCs from forest environments}

We explore three contrasting forest regions throughout 2014 (Fig. 1), characterized by latitude-dependent levels of photosynthetically active radiation (PAR) and by their proximity to urban emissions. We focus on the yield of $\mathrm{HCHO}$ from the emission of isoprene (Palmer et al., 2003). 
Table 2. Results of the photochemical box modelling for forested region scenarios (Table 1).

\begin{tabular}{lccc}
\hline Scenario & $\begin{array}{c}\text { Isoprene lifetime } \\
{[\mathrm{min}]}\end{array}$ & $\begin{array}{c}\text { Time to reach peak HCHO signal } \\
{[\mathrm{min}]}\end{array}$ & $\begin{array}{c}\text { HCHO yield } \\
{[\text { per-C] }}\end{array}$ \\
\hline E01 & 26 & 79 & 0.50 \\
E05 & 14 & 59 & 0.55 \\
E08 & 10 & 33 & 0.49 \\
E11 & 20 & 83 & 0.41 \\
\hline NE01 & 28 & 89 & 0.59 \\
NE05 & 10 & 33 & 0.38 \\
NE08 & 10 & 33 & 0.58 \\
NE11 & 18 & 57 & 0.53 \\
\hline S01 & 64 & 127 & 0.63 \\
S05 & 48 & 147 & 0.63 \\
S08 & 70 & 189 & 0.66 \\
S11 & 52 & 153 & 0.62 \\
\hline
\end{tabular}

We report the resulting lifetime of the injected isoprene for each calculation (Sect. 2.2.1), in addition and the cumulative per-C HCHO yield (Table 2). We find that the duration of the calculation is sufficiently long that the peak $\mathrm{HCHO}$ had time to diminish to a negligible amount.

The atmospheric lifetime of isoprene against $\mathrm{OH}$ is typically much shorter than an hour, with shortest values ( $<15 \mathrm{~min}$ ) during summer months. The most southern site, in the state of Kerala (Fig. 1), is where isoprene has the longest lifetime. This is due to $\mathrm{OH}$ being suppressed by high ambient $\mathrm{NO}_{2}$ concentrations (in excess of $8 \mathrm{ppbv}$ ) originating from the coastal conurbation in that state. We find that levels of $\mathrm{NO}_{x}$ are sufficiently high (averages generally around or above $1 \mathrm{ppbv}$ ) in all forested regions such that isoprene peroxy radicals preferentially react with NO to rapidly produce $\mathrm{HCHO}$. Peak values for $\mathrm{HCHO}$ production are typically reached within $90 \mathrm{~min}$ of the isoprene oxidation. The $\mathrm{OH}$ suppression in Kerala is primarily responsible for the slow production of $\mathrm{HCHO}$. We report that the peak $\mathrm{HCHO}$ signal is typically reached within $30-90 \mathrm{~min}$, corresponding to a smearing length scale of $9-27 \mathrm{~km}$ assuming an example wind speed of $5 \mathrm{~m} \mathrm{~s}^{-1}$. For the Kerala region where the time taken to reach the peak $\mathrm{HCHO}$ signal is typically $2-3 \mathrm{~h}$ the corresponding smearing length scale is $36-54 \mathrm{~km}$. Even in Kerala the smearing length is comparable to the longitudinal extent of a single OMI scene and well within the swath width (Sect. 2). Figure 3 shows that the corresponding values of the per-C HCHO yield ranges from 0.38 to 0.66 . Higher values are generally associated with higher values of $\mathrm{NO}_{x}$ (cf. $\mathrm{NO}_{2}$ mixing ratios in Table 1 and yields reported in Table 2), consistent with previous studies (Palmer et al., 2006; Barkley et al., 2013). The simulations reported in this work are specific to the Indian scenarios discussed.

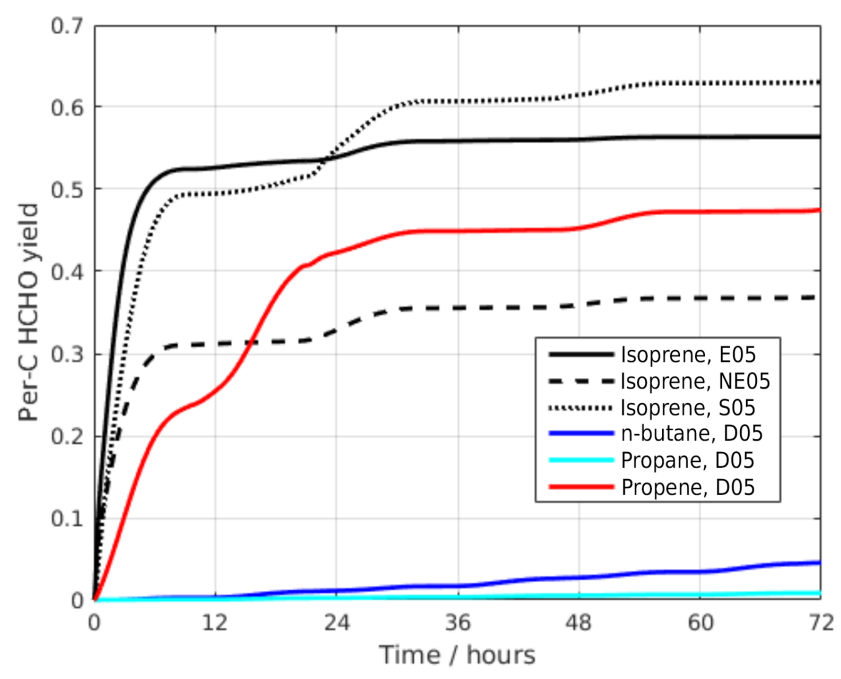

Figure 3. Time-dependent cumulative $\mathrm{HCHO}$ yield (per-C) produced from isoprene in three contrasting photochemical environments, and from propene, propane, and $n$-butane in an urban photochemical environments based on Delhi. Calculations are denoted by an alphanumeric code that is explained in Table 1 .

\subsubsection{Anthropogenic VOC in urban environment}

To study the role of anthropogenic non-methane VOCs (NMVOCs) in determining HCHO columns we simulate boundary layer chemistry over Delhi using emissions from the MIX emission inventory ( $\mathrm{Li}$ et al., 2017). Over major cities, NMVOC emissions originate mainly from stationary combustion and the transport sector. The species in the MIX inventory are defined following the SAPRC99 chemical mechanism (Carter, 2000). From a comparison of the correlation coefficients we find that over Delhi, according to the MIX inventory, NMVOC emissions include propane, propene, and ALK4, representing 13, 32, and $55 \%$ 


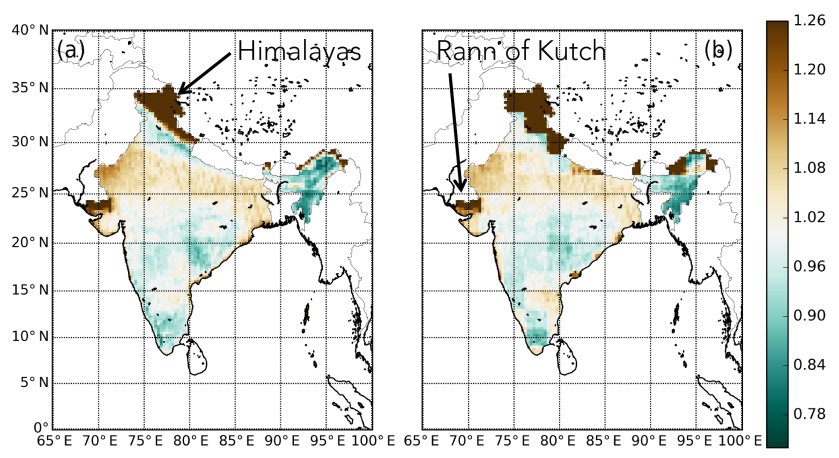

Figure 4. Annual mean air mass factors (AMFs) for 2014 calculated using (a) nested $0.25^{\circ} \times 0.3125^{\circ}$ and (b) standard $2.0^{\circ} \times 2.5^{\circ}$ GEOS-Chem grid.

of NMVOC $\mathrm{C}$ emissions. ALK4 denotes $>\mathrm{C}_{4}$ alkanes. The longest chain alkane in the 0-D chemical mechanism is $n$ butane. We denote this urban model scenario as "D05" (Table 1). We calculate individual $\mathrm{HCHO}$ yields from the oxidation of propane, propene, and $n$-butane.

Propene $\left(\mathrm{CH}_{3} \mathrm{CH}=\mathrm{CH}_{2}\right)$ has an atmospheric lifetime of several hours, determined by $\mathrm{OH}$ addition to its double bond. The major intermediate products include $\mathrm{HCHO}$ and acetaldehyde. The ultimate $\mathrm{HCHO}$ yield from the oxidation of propene (close to 0.5 ) is comparable with the value from isoprene oxidation (Fig. 3) but it only reaches $50 \%$ of that final value within 12 hours, consistent with the longer lifetime of propene. Propane and $n$-butane have atmospheric lifetimes of 10 and 5 days, respectively, determined by $\mathrm{OH}$. Long-lived intermediate oxidation products include acetone that further delay the production of $\mathrm{HCHO}$ (Fig. 3).

Assuming an average wind speed of $3 \mathrm{~m} \mathrm{~s}^{-1}$, taken from wind measurements at Indira Gandhi airport in Delhi, only $\mathrm{HCHO}$ production from the oxidation of propene (out of all the gases that represent a major contribution to the regional emission inventory) would produce a signal that could potentially be distinguishable above the ambient concentration. We later show that there is some evidence that a Delhi HCHO hotspot can be observed but only after temporally oversampling the data.

\subsection{OMI and GEOS-Chem model HCHO column distributions}

\subsubsection{Data filtering and AMF statistics}

Using the data quality criteria, as defined above, we remove $58 \%$ of all OMI HCHO measurements collected during 2014. The proportion of data removed per month varies during the year, with most scenes removed during the cloudy monsoon season in July $(71 \%)$ and the least number of scenes removed during March (45\%).

Figure 4 shows the annual mean distribution of AMFs across India, with values ranging from 0.7 to 1.5 and a me- dian value of 1 . AMF values are highest in the Himalayas at the extreme north of India, which are often covered by snow, and over the Rann of Kutch salt marsh. In both cases, elevated $A M F$ values are due to high surface albedos.

To determine the influence of the AMFs on the spatial distribution of $\mathrm{HCHO}$ vertical columns we compare fitted OMI slant HCHO columns and the corresponding vertical columns to the GEOS-Chem model. We find that the vertical columns reproduce $11 \%$ more of the model spatial distribution than the observed slant columns, consistent with past studies (Palmer et al., 2001; Millet et al., 2008) that show that the AMF plays only a minor role in the observed spatial distribution of vertical HCHO columns.

To investigate the role of model resolution in our calculation of vertical columns we repeated the annual mean analysis using the $2^{\circ} \times 2.5^{\circ}$ version of the GEOS-Chem driven by the same inventories as described above. Figure 5 shows that the coarser resolution model fails to reproduce smaller-scale variations, as expected, which defines much of the Indian west coast, and misses variations over northeastern India. While the model via the AMF calculation only contributes a small amount to the distribution of $\mathrm{HCHO}$ vertical columns it does affect the magnitude of the columns. We find that there is an overwhelming argument to justify the use of the higherresolution model.

\subsubsection{Annual mean spatial distribution}

Figure 5 shows the annual mean model and observed HCHO columns for 2014. The lowest observed and model columns are in the north of the study region coinciding with the Himalayas and (to a lesser extent) in the Thar Desert in the northwest. The observations show three main regions associated with elevated HCHO columns: (1) the non-Himalayan part of the northeast region of India, east of Bangladesh; (2) territory at the south of the country, around the southern part of the Western Ghats mountain range, roughly following the borders of the state of Kerala; and (3) a broad area over the east of the country, roughly outlined by the states of Chhattisgarh, Odisha, and the northern part of Andhra Pradesh.

The nested GEOS-Chem model reproduces the observed magnitude and broad-scale spatial distribution of OMI HCHO columns over India (Fig. 5), but is much smoother. The model has a small but positive bias of $14 \%(12 \%)$ for the mean (median) annual column amounts. We find that the model captures $33 \%(r=0.58)$ of the observed annual mean spatial variation of HCHO columns. The major discrepancy between the model and observed annual mean HCHO distributions is over the IGP and over Delhi. Observed HCHO columns are elevated over the IGP but not to the values shown in the model, which we discuss below. A HCHO hotspot over Delhi is apparently absent from the OMI columns, but as we show later there is evidence that the hotspot exists in the observations. 

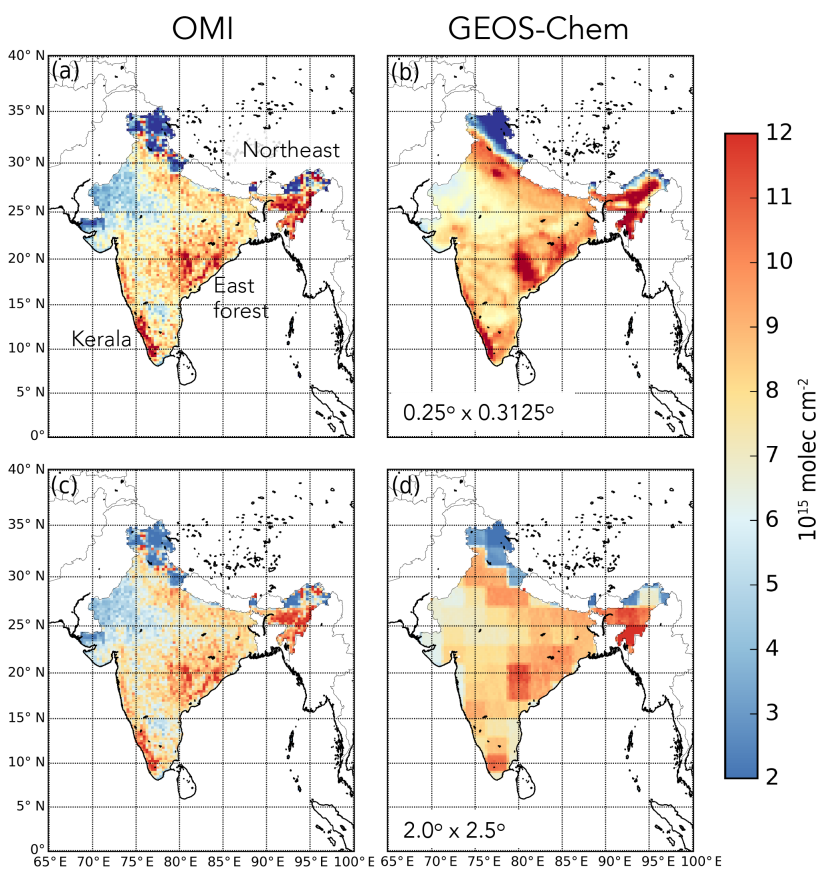

Figure 5. Annual mean clear-sky (a, c) OMI and (b, d) GEOSChem HCHO vertical columns $\left(10^{15}\right.$ molec $\left.\mathrm{cm}^{-2}\right)$ over India for 2014. The OMI vertical columns are described on the $0.25^{\circ} \times$ $0.3125^{\circ}$ GEOS-Chem grid. These vertical columns are transformed from observed slant columns using AMFs informed by the distribution of $\mathrm{HCHO}$ described by the $(\mathbf{a}, \mathbf{b})$ nested $0.25^{\circ} \times 0.3125^{\circ}$ and (c, d) standard $2.0^{\circ} \times 2.5^{\circ}$ GEOS-Chem grid. Data exclusion criteria are described in the main text. The model is sampled at the time and location of each observed scene.

Based on the box modelling, the largest source of HCHO column variability is expected to be isoprene emissions. Figure 1 shows that the broad-scale annual distribution of HCHO over India is consistent with the annual mean distribution of Normalized Diffusive Vegetation Index (NDVI) with a Pearson correlation of $r=0.49$. Below, we use seasonal variations of $\mathrm{HCHO}$ columns to improve understanding of the drivers.

\subsection{Seasonal spatial distributions}

Figure 6 shows OMI and GEOS-Chem model HCHO columns for seasons during 2014. There are distinct seasonal cycles to the HCHO columns over three broad regions: northeastern India, southwestern India, and over the IGP. Over (north)eastern India HCHO columns peak in premonsoon and monsoon months. Columns over southwestern coast of India peak in winter and pre-monsoon months and are very low in other seasons. Columns over the IGP are elevated above those elsewhere in northern Indian during pre-monsoon months and peak in monsoon months. Figure 7 shows that the timing of these elevated columns coincide with warmer surface temperatures. This suggests a role

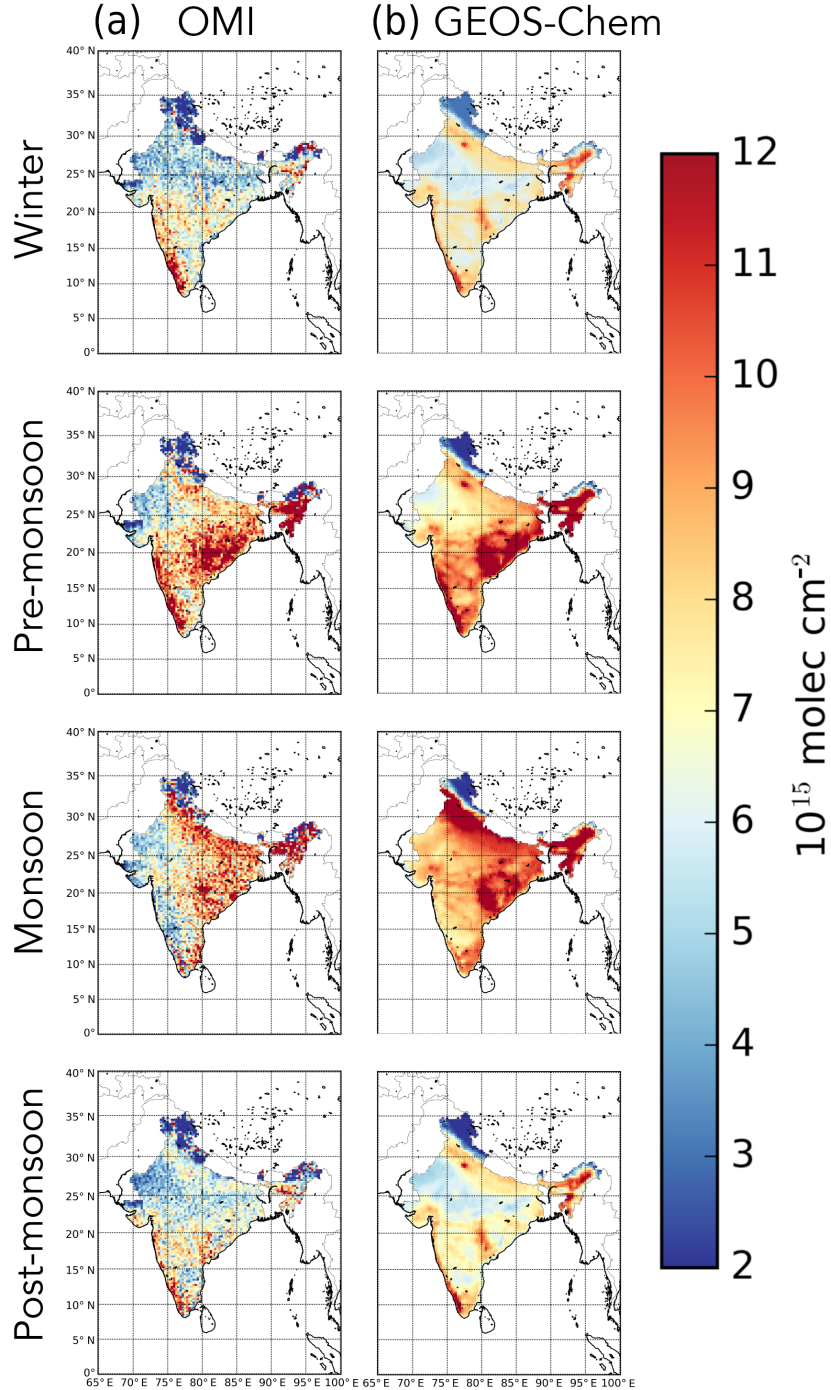

Figure 6. Seasonal mean clear-sky (a) OMI and (b) GEOS-Chem HCHO vertical columns $\left(10^{15}\right.$ molec $\left.\mathrm{cm}^{-2}\right)$ for 2014, averaged on a common $0.25^{\circ} \times 0.3125^{\circ}$ grid. Seasonal definitions are described in Sect. 2.

for biogenic VOC emissions, consistent with the strong, local relationship between isoprene emissions and $\mathrm{HCHO}$ production that we demonstrated above.

The GEOS-Chem model captures these broad-scale observed distributions of $\mathrm{HCHO}$ but is much smoother, as expected. We find the model has some skill at reproducing the observed spatial distribution with a Pearson correlation $r$ of $>0.4$, with larger values in winter and pre-monsoon months ( $r=0.50$ and 0.62 , respectively) and smaller values in monsoon and post-monsoon months $(r=0.39$ and 0.44 , respectively). On an annual timescale the model has a positive bias of $1.0 \times 10^{15}$ molec $\mathrm{cm}^{-2}(33 \%)$, which is skewed due to a large bias during the monsoon months $\left(1.9 \times 10^{15}\right.$ molec $\left.\mathrm{cm}^{-2}, 17 \%\right)$. The model has a more defined peak over Delhi, peaking in monsoon months, but there 

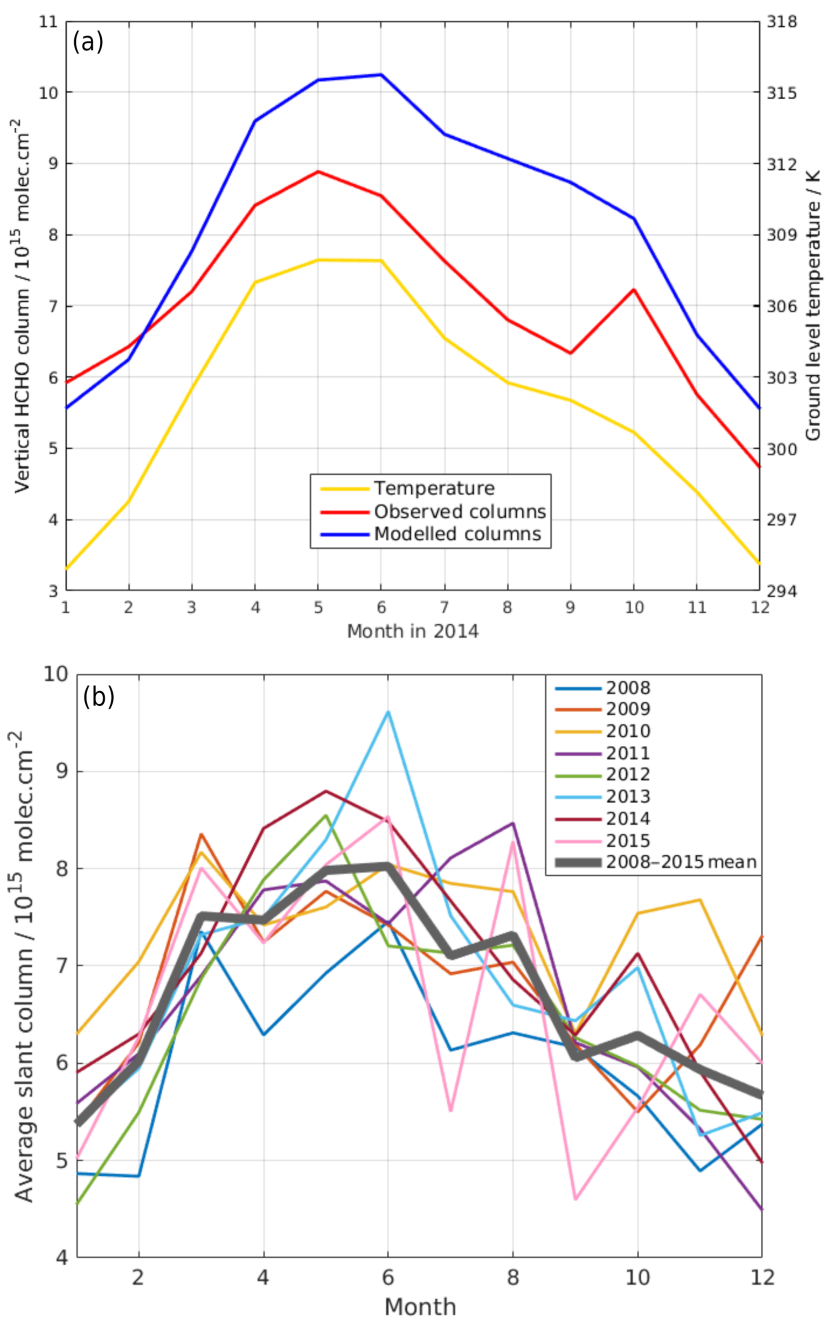

Figure 7. Time series of (a) OMI and GEOS-Chem vertical

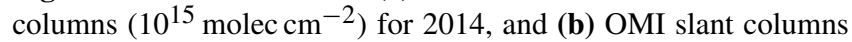
$\left(10^{15} \mathrm{molec}^{-2}\right)$ from 2008 to 2015 over India. GEOS-FP ground-level temperature $(\mathrm{K})$ is also shown in the top panel. The thick grey line in the bottom panel denotes 2008-2015 HCHO column monthly means.

is only a small, diffuse peak in the observations. We discuss this discrepancy below.

Figure 7 shows that on a continental scale the seasonal distribution of HCHO slant columns over India in 2014 is not significantly different from observed distributions from 2008 to 2015. In general, HCHO columns follow a similar cycle in the winter and pre-monsoon months, but there are substantial year-to-year variations during the monsoon and post-monsoon months suggesting a role for large-scale variation in meteorology associated with the monsoon. Figure 8 shows the corresponding differences in the spatial distribution of HCHO columns from 2014 compared to the mean 2008-2015 distribution. Median HCHO columns for 2014 are slightly higher than the 8 -year average by $0.4 \times$ $10^{15} \mathrm{molec}^{-2}$, but show a similar spatial distribution tak- (a) 2014

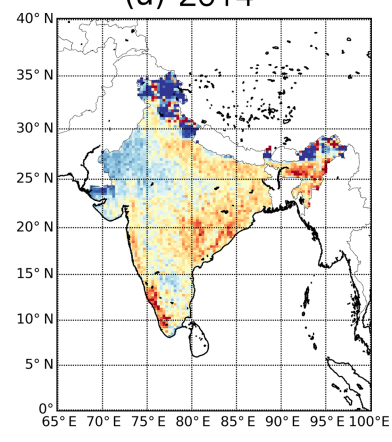

(b) Mean: 2008-2015

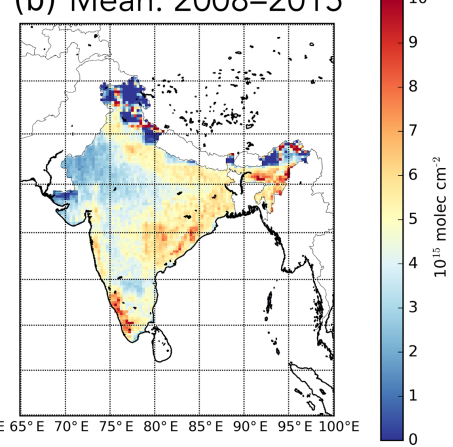

Figure 8. Annual mean OMI HCHO slant columns $\left(10^{15} \mathrm{molec} \mathrm{cm}^{-2}\right)$ over India for (a) 2014 and (b) 2008-2015, averaged on a common $0.25^{\circ} \times 0.3125^{\circ}$ grid.

ing into account year-to-year variability (Fig. 7). Mahajan et al. (2015) reports an analysis of the drivers of year-to-year variations in $\mathrm{HCHO}$ columns over India.

\subsubsection{Biogenic VOCs}

Figure 7 shows that the observed continental-scale HCHO seasonal cycle is reproduced by the model but with a positive model bias typically within $1 \times 10^{15} \mathrm{molec}^{-2}$. On this spatial scale, most of the seasonal cycle can be explained by variations in surface temperature, suggesting a larger than expected role for biogenic emissions. However, the model fails to capture the elevated monthly column during October 2014. We find this is driven mostly by observed variations in HCHO columns over tropical India, coinciding with the withdrawal of the monsoon from India between late September and mid-October (Pai and Bhan, 2015). We suggest this variation represents a response from the vegetation that is missing in the model. Model error associated with cloud coverage and consequent errors associated with the partitioning between direct and diffuse PAR could result in large-scale changes in biogenic emissions.

The only forested region that is an exception to the continental-scale picture is over Kerala (denoted by $\mathrm{S}$ in Fig. 1). Kerala has a tropical maritime climate with little seasonal variation in temperature. The forested region in Kerala neighbours an urban conurbation associated with a high level of $\mathrm{NO}_{x}$ (Fig. 9), which influence the $\mathrm{HCHO}$ yields from the oxidation of biogenic VOCs, as described in Sect. 3.1. Fig. 10 shows that the observed seasonal distribution of HCHO columns at this site, broadly reproduced by the model, peaks during the winter and is lowest during premonsoon and monsoon months. The size of the seasonal variation in HCHO columns is not fully explained by the small seasonal variation in surface temperature, suggesting a role for an additional driver. Figure 10 shows that over this region, the seasonal distribution is driven mostly by changes in leaf phenology rather than temperature or PAR. Satellite 


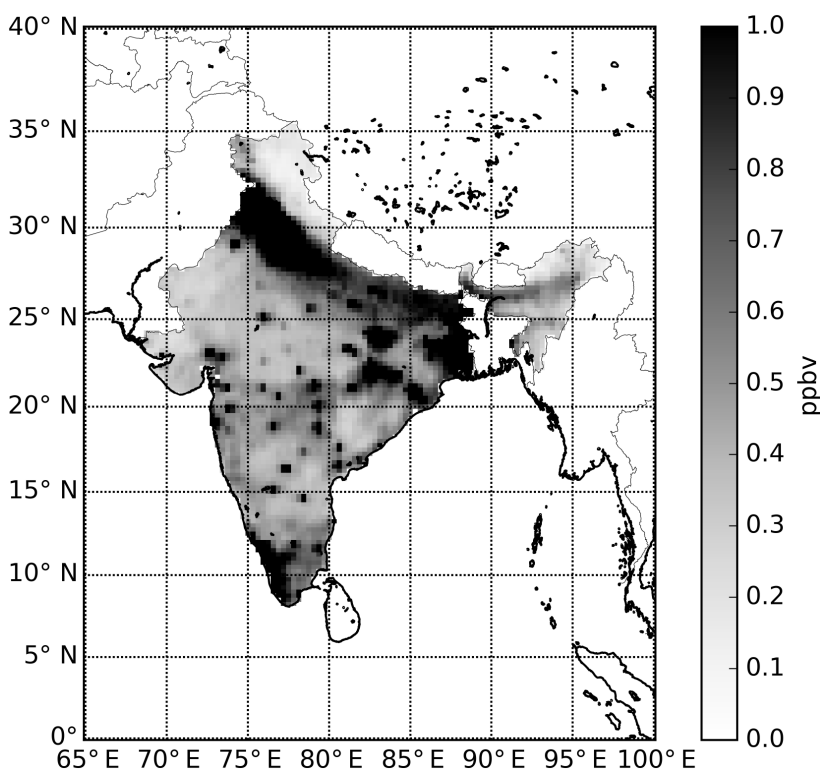

Figure 9. Annual mean GEOS-Chem ground-level $\mathrm{NO}_{x}$ mixing ratios (ppbv) in 2014 , averaged on the $0.25^{\circ} \times 0.3125^{\circ}$ grid.

observations of LAI drop from $\simeq 4$ to $\simeq 1 \mathrm{~m}^{2} \mathrm{~m}^{-2}$ during the monsoon months and recover in the post-monsoon months. We find similar behaviour over the eastern and northeastern forests with large reductions in LAI during monsoon months (not shown). This behaviour is consistent with vegetation taking advantage of the decreased temperatures and higher precipitation rates during the monsoon season to regulate leaf flushing.

Past work has found a contrasting relationship between leaf phenology and satellite observations of HCHO columns over the Amazon Basin (Barkley et al., 2009) in which $\mathrm{HCHO}$ columns and LAI values dropped in the transition period between the wet and dry seasons, and recovered soon afterwards. Thermotolerance is one hypothesis that describes why leaves emit isoprene (Singaas et al., 1997). A few weeks after emerging, the emission capacity of leaves peaks and subsequently declines with age. To explain the variation in HCHO columns, (Barkley et al., 2009) proposed wide-scale leaf flushing that allowed vegetation to maximize their protection against the light-rich environment of the dry season. A demographic model of leaf phenology based on the hypothesis that trees seek an optimal LAI as a function of available light and soil water (Caldararu et al., 2012, 2014) explained the observed increase in LAI over the Amazon Basin during the dry season as a net addition of leaves in response to increased solar radiation.

\subsubsection{Pyrogenic VOCs}

The main loci for biomass burning are as follows: (1) a region approximately encompassed by the state boundaries of Punjab and Haryana (Fig. 1) and (2) northeastern India. The
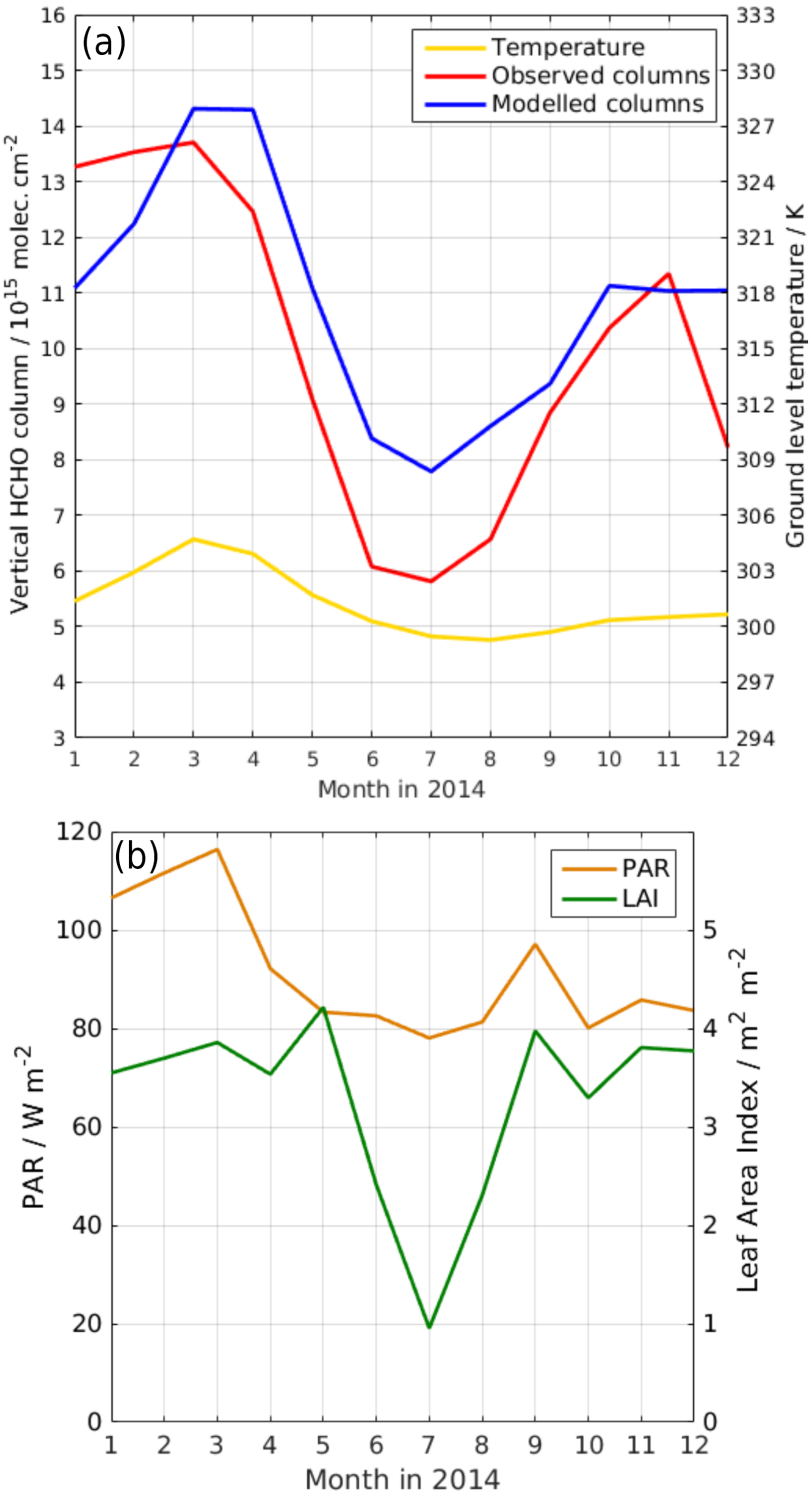

Figure 10. Time series of (a) monthly mean OMI and GEOSChem vertical HCHO columns $\left(10^{15}\right.$ molec $\left.\mathrm{cm}^{-2}\right)$, and GEOS-FP ground-level temperature; and time series of (b) PAR $\left(\mathrm{W} \mathrm{m}^{-2}\right)$ and LAI $\left(\mathrm{m}^{2} \mathrm{~m}^{-2}\right)$ over the state of Kerala in 2014.

states of Punjab and Haryana have two growing seasons, May-September (rice) and November-April (wheat). Paddy stubble burning in May and October/November represents agriculture burning of wheat and rice residue, respectively. For our purposes northeastern India includes the "Seven Sister States" (Arunachal Pradesh, Assam, Meghalaya, Manipur, Mizoram, Nagaland, and Tripura), where there are significant forest fires particularly during March and April. This is mainly due to deforestation to convert forests to agricultural land (Santenda and Kaushik, 2014). These two geographical regions account for more than $70 \%$ of these emissions during 2014. 

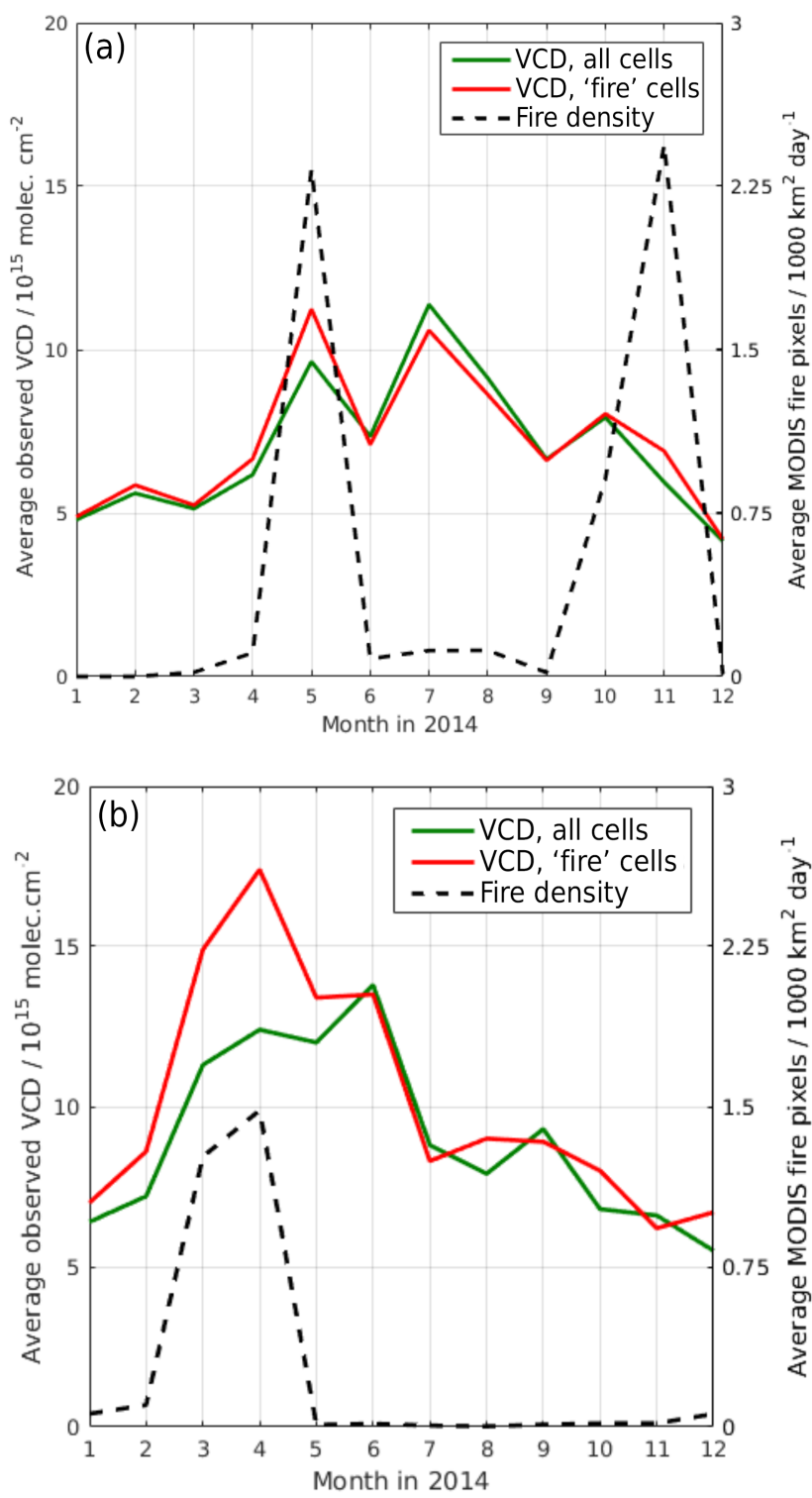

Figure 11. Time series of monthly mean HCHO columns $\left(10^{15}\right.$ molec $\left.\mathrm{cm}^{-2}\right)$ and the number of MODIS fire detections $\left(10^{3} \mathrm{~km}^{2}\right.$ day $\left.^{-1}\right)$ over (a) the states of Punjab and Haryana and (b) northeastern India. The green line denotes all HCHO columns over the region, and the red line denotes columns that are most affected by fires as indicated by MODIS fire counts.

To illustrate the impact of fires on HCHO column variations we use MODIS fire count data (Justice et al., 2002) to identify when and where fires occur over the states of Punjab and Haryana, and Northeastern India. We calculate monthly mean $\mathrm{HCHO}$ vertical columns and fire counts. We then determine which $0.25^{\circ} \times 0.3125^{\circ}$ grid cells are most affected by fires by selecting these cells in the top 20th percentile of cumulative fires.

Figure 11 shows that the highest number of fire counts generally correspond to when there is the largest differ- ence between all grid cells and those most affected by fire. This difference is relatively small over the states of Punjab and Haryana with a peak value of $1.5 \times 10^{15}$ molec cm $^{-2}$ during May. There is a large difference during March and April over the northeastern India where fires contribute up to $5 \times 10^{15}$ molec $\mathrm{cm}^{-2}$ to the monthly mean. We find that this contribution to $\mathrm{HCHO}$ columns is localized in time and geography.

\subsubsection{Anthropogenic hotspots}

Guided by a priori emissions and our box modelling, we anticipate that propene is the only anthropogenic VOC likely to produce $\mathrm{HCHO}$ rapidly enough that we can relate elevated $\mathrm{HCHO}$ columns to emissions. However, we find little evidence that seasonally averaged OMI HCHO columns are elevated over Indian megacities due to limits in the signal to noise, in agreement with previous work (Mahajan et al., 2015)

We use a temporal oversampling approach, following (Zhu et al., 2014), to improve the spatial resolution of $\mathrm{HCHO}$ columns over Delhi and the surrounding region. Oversampling increases the signal-to-noise ratio and allows for inspection of finer spatial features, at the expense of the temporal information. We focus on Delhi because the National Capital Region has a population of approximately 17 million people (Perianayagam and Goli, 2012) over a geographical area of approximately $2000 \mathrm{~km}^{2}$. Based on the MIX emissions inventory, which is indicative of values from 2010, (Fig. 6) we expect to see an elevated signal from this region. This bottom-up emission inventory likely overestimates emissions from the transport sector, which has seen the biggest change from 2010 to 2014 (Jun-ichi Kurokawa, personal communication, Japan Environmental Sanitation Center, October 2017).

First, our area of focus is divided into a very high resolution grid $\left(0.02^{\circ} \times 0.02^{\circ}\right)$. The temporally averaged column for each point in this grid is the average of the OMI observational vertical columns collected during 2014 with the centre point within $43 \mathrm{~km}$ in both the latitudinal and longitudinal directions. This effectively smears out these observations over $43 \mathrm{~km}$ squares. Here, we average over $43 \times 43 \mathrm{~km}^{2}$ squares rather than the $24 \mathrm{~km}$ radius circles, sampling all the 2014 vertical HCHO columns from the observational dataset for the area around Delhi.

Figure 12 shows that the oversampling method results in distinct elevated HCHO columns over New Delhi and along major roadways, although the gradients are still noisy. The magnitude of this elevation is $\mathcal{O}\left(10^{15}\right)$ molec $\mathrm{cm}^{-2}$. Elevated areas to the east and southeast of the city may represent $\mathrm{HCHO}$ produced from VOC transported downwind from Delhi. Based on our results we find that anthropogenic emissions do not appear to play a large role in the observed column variations of $\mathrm{HCHO}$ over India. 


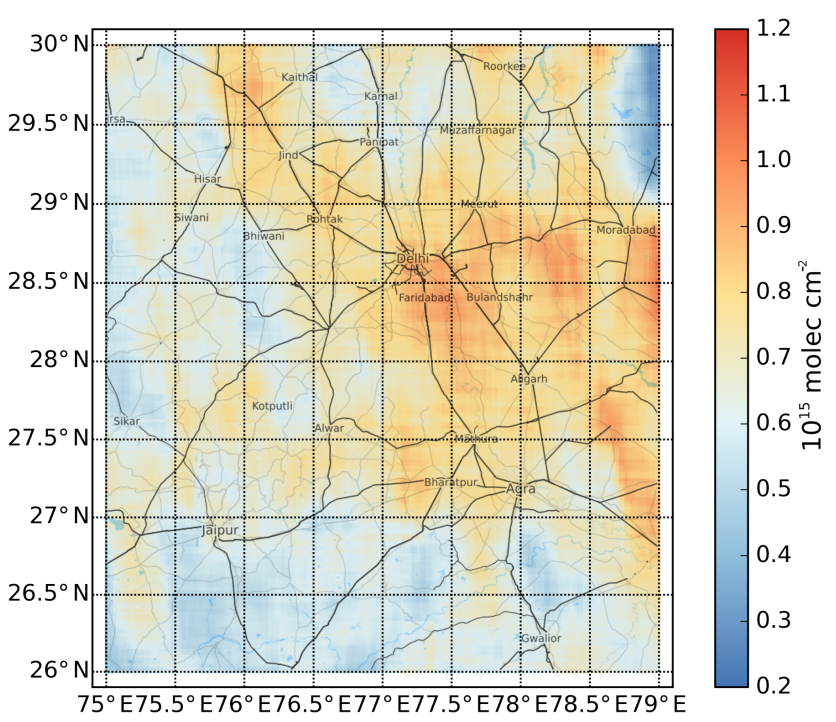

Figure 12. Oversampled distribution of OMI vertical $\mathrm{HCHO}$ columns $\left(10^{15}\right.$ molec $\left.\mathrm{cm}^{-2}\right)$ around Delhi. The underlying road network is reproduced with permission from (c) www.thunderforest. com (map) and from (C) www.osm.org/copyright (data).

However, our use of $\mathrm{HCHO}$ columns from the OMI instrument, which has a local overpass time of 13:30, may be hindering our ability to observe the anthropogenic contribution to HCHO. Biogenic emissions and to a lesser extent biomass burning emissions peak in the early afternoon hours, which is ideal for OMI. Emissions from the transportation sector, a major source of anthropogenic VOCs, peak during the early morning and late afternoon associated with commuter traffic. We argue that the early morning 09:30 overpass of the Global Ozone Monitoring Experiment (GOME2) aboard the MetOp satellite is better suited to capture these anthropogenic emissions. Secondary production of $\mathrm{HCHO}$ is generally larger than direct emissions of $\mathrm{HCHO}$, and will occur a few hours after the peak commuter time (e.g. Lin et al., 2012; Wang et al., 2017). The early morning rush hour in Delhi starts after 07:00 so we expect a 09:30 overpass to also capture some fraction of the secondary HCHO production. Using data collected from morning and afternoon overpass times to describe diurnal variations of $\mathrm{HCHO}$ was presented by (De Smedt et al., 2015), but they did not discuss the relative importance of different VOC emission sources at these different times.

Figure 13 shows the annual mean HCHO columns observed by GOME-2 and OMI. For our preliminary argument we are only interested in the distribution of $\mathrm{HCHO}$ columns. Here, we have standardized these data for the whole country so that they have a mean of zero and a unit standard deviation using:

$z_{i}=\frac{x_{i}-\bar{x}}{s}$, (a) GOME-2



(b) OMI

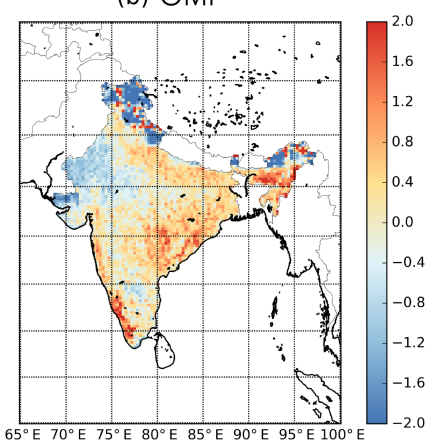

Figure 13. Standardized HCHO slant columns for 2014 (unitless) from (a) the Global Ozone Monitoring Experiment-2 (GOME2) aboard MetOp and (b) OMI, averaged on a common $0.25^{\circ} \times$ $0.3125^{\circ}$ grid. GOME-2 and OMI have local equatorial overpass times of 09:30 and 13:30, respectively.

where $x_{i}$ is a data point, $\bar{x}$ is the sample mean, and $s$ is the sample standard deviation. This allows us to compare the two data without worrying about bias. The resulting $z$ scores represent the number of standard deviations from the population mean. We find that GOME-2 data has higher columns over the IGP, while OMI more clearly emphasizes the forested regions that we can identify independently through LAI or NDVI measurements (Fig. 1). This qualitative test appears to support our hypothesis and is an early demonstration of how datasets with continuous measurements of a region (such as those from a geostationary satellite) could help capture the temporal variability of HCHO. Taking advantage of the complementary information from multiple sensors that have different local overpass time requires a sophisticated inverse model approach.

\subsection{Inferring isoprene emissions from OMI HCHO columns}

Based on our analysis of the HCHO yields from Indian VOC sources, and the distribution of observed HCHO columns we conclude that the majority of the observed HCHO column variation is due to biogenic VOC emissions. Here, we adopt a simple inversion methodology based on linear regression to infer isoprene emissions from OMI HCHO columns (Palmer et al., 2006).

First, we filter HCHO column data over India to minimize any interference from pyrogenic and anthropogenic sources. We focus on two relatively remote areas of India: "East" approximately defined as the area spanning $16-25^{\circ} \mathrm{N}$ and $76-87^{\circ} \mathrm{E}$, and "Northeast" defined as the region of India east of $90^{\circ} \mathrm{E}$ (Fig. 1). We remove scenes with MODIS land cover classifications (Friedl et al., 2010) corresponding to croplands (including cropland mosaics), urban/builtup, snow/ice, barren/sparsely vegetated, and water bodies. We also filter out potential fire-affected data by identifying, 
Table 3. A priori and a posteriori isoprene emission estimates $\left(10^{11}\right.$ atom $\left.\mathrm{C} \mathrm{cm}^{-2} \mathrm{~s}^{-1}\right)$ over NE and E forest sites (Fig. 1), and the model linear regression coefficients that relate model isoprene emissions and $\mathrm{HCHO}$ columns.

\begin{tabular}{|c|c|c|c|c|c|c|}
\hline \multirow[b]{2}{*}{ Season } & \multicolumn{6}{|c|}{ East forest region } \\
\hline & $\begin{array}{l}\text { Mean a priori emission } \\
{\left[10^{11} \text { atom } \mathrm{C} \mathrm{cm}^{-2} \mathrm{~s}^{-1}\right]}\end{array}$ & $\begin{array}{l}\text { Slope } S \\
{\left[10^{3} \mathrm{~s}\right]}\end{array}$ & $\begin{array}{r}\text { Intercept } \Omega_{b} \\
{\left[10^{15} \text { molec cm }^{-2}\right]}\end{array}$ & $r^{2}$ & $\begin{array}{l}\text { Mean a posteriori emission } \\
\qquad\left[10^{11} \text { atom } \mathrm{C} \mathrm{cm}^{-2} \mathrm{~s}^{-1}\right]\end{array}$ & $\begin{array}{l}\% \text { change } \\
\text { from a priori }\end{array}$ \\
\hline Winter & 2.8 & 4.1 & 5.3 & 0.59 & 3.0 & +7 \\
\hline Pre-monsoon & 10.2 & 4.3 & 7.0 & 0.67 & 7.8 & -24 \\
\hline Monsoon & 7.4 & 4.3 & 7.6 & 0.51 & 3.3 & -55 \\
\hline \multirow[t]{2}{*}{ Post-monsoon } & 3.6 & 4.9 & 5.2 & 0.47 & 2.6 & -28 \\
\hline & \multicolumn{6}{|c|}{ Northeast forest region } \\
\hline Winter & 3.5 & 3.9 & 3.9 & 0.42 & 4.4 & +26 \\
\hline Pre-monsoon & 17.9 & 2.9 & 6.2 & 0.58 & 12.6 & -30 \\
\hline Monsoon & 14.6 & 2.2 & 8.7 & 0.27 & 1.7 & -88 \\
\hline Post-monsoon & 6.6 & 4.9 & 5.1 & 0.49 & 2.7 & -59 \\
\hline
\end{tabular}

for each day, the cells of the $0.25^{\circ} \times 0.3125^{\circ}$ grid in which fires are reported in the MODIS active fire product. The data from these, and the adjacent cells, are then removed for that day as well as the preceding and succeeding days, following Barkley et al. (2013).

Second, we determine the model relationship between local isoprene emissions $E$ (molec $\left.\mathrm{cm}^{-2} \mathrm{~s}^{-1}\right)$, as calculated by MEGAN (Guenther et al., 2012), and HCHO columns $\Omega$ $\left(\right.$ molec $\left.\mathrm{cm}^{-2}\right)$ :

$\Omega=S E_{\mathrm{VOC}}+\Omega_{b}$,

where the slope $S$ represents the production of HCHO column per emission of isoprene, and the intercept $\Omega_{b}$ represent the HCHO column contributions from longer-lived VOCs mainly from the oxidation of methane. We resolve seasonal a priori emissions of isoprene from observed HCHO columns by transposing the model linear relationship between isoprene emissions and $\mathrm{HCHO}$ columns.

For both study regions, we find a statistically significant linear relationship between those variables (Table 3), where Pearson correlation coefficients $r$ range from 0.52 to 0.82 , with a typical value in excess of 0.70 . The slope values $\left(10^{3} \mathrm{~s}\right)$ vary with region and season. The offsets that represent the background $\mathrm{HCHO}$ column is higher during the pre-monsoon and monsoon summer months when we expect larger $\mathrm{HCHO}$ production from a range of longer-lived VOC (including $\mathrm{CH}_{4}$ ), due to higher values of $\mathrm{OH}$.

Our a posteriori emission estimates are generally lower than a priori values, reflecting the positive model $\mathrm{HCHO}$ column bias. This is most pronounced over the northeastern region during the monsoon season, where a posteriori isoprene emissions are $88 \%$ lower than a priori estimate, due to the model not capturing the sharp observed decline in $\mathrm{HCHO}$ that appears to be linked with monsoon conditions. We acknowledge that the bias between model and OMI HCHO columns could also reflect a bias in the OMI data (Zhu et al.,
2016) but without independent measurements over this region we have chosen to assign these biases exclusively to the model.

\section{Concluding remarks}

We used models of atmospheric chemistry to interpret HCHO column distributions during 2014 observed by the Ozone Monitoring Instrument (OMI) satellite instrument over India. The annual mean OMI distribution of clear-sky $\mathrm{HCHO}$ columns is dominated by a distinctive meridional gradient in the northern half of the country, and by localized regions of high columns that coincide with forests. We found that the nested GEOS-Chem atmospheric chemistry model (spatially resolved at $\simeq 25 \mathrm{~km}$ ) reproduces these broad-scale observed features with a positive model bias, particularly over the Indo-Gangetic Plain and Delhi.

Over India, HCHO has biogenic, pyrogenic, and anthropogenic sources of volatile organic compounds (VOCs), some of which are spatially and temporally disaggregated. Using the CAABA 0-D photochemistry model, we explored a range of forest and urban photochemical environments found over India and their subsequent influence on $\mathrm{HCHO}$ concentrations. HCHO columns are related to local VOC emissions with a spatial smearing that increases with the VOC lifetime. We found that isoprene has the largest molar yield of HCHO which is typically realized within a few hours in the presence of moderate levels of nitrogen oxides ( $\simeq 1 \mathrm{ppbv}$ ), in agreement with previous studies. However, we also found that forested regions that neighbour major urban conurbations (e.g. in the state of Kerala) are exposed to much higher levels of nitrogen oxides $(\simeq 8 \mathrm{ppbv})$. This results in depleted hydroxyl radical concentrations and a delay in the production of $\mathrm{HCHO}$ from isoprene oxidation. Informed by a regional bottom-up emission inventory for India, we found that propene is the only major component of anthropogenic 
VOCs that produces $\mathrm{HCHO}$ at comparable (but slower) rate to isoprene.

We found that the GEOS-Chem model reproduces observed spatial distributions during winter (JF) and premonsoon months (MAM) better than during monsoon (JJAS) and post-monsoon (OND) months. We attributed these differences in model skill to the response of the natural biosphere to changes in the meteorological and photochemical environments associated with the onset and retreat of the monsoon. We found that on a continental scale much of the seasonal cycle in observed HCHO columns can be explained by monthly variations in surface temperature. This observation together with the strong local relationship we found between isoprene emissions and $\mathrm{HCHO}$ production suggests a role for biogenic VOCs, in agreement with the GEOS-Chem model calculation. We also found that the seasonal cycle during 2014 is not significantly different from the 2008 to 2015 mean seasonal variation but there are large year to year variations. There are two main loci for biomass burning (states of Punjab and Haryana, and northeastern India), which we found makes a significant contribution (up to $1 \times 10^{15}$ molec $\mathrm{cm}^{-2}$ ) to observed columns only during March to April over northeastern India. The slow production of $\mathrm{HCHO}$ from propene oxidation results in a smeared hotspot over Delhi that we could only resolve by using a temporal oversampling method. Based on comparing GOME2 and OMI HCHO column distributions, we argue that the early morning overpass time is better for quantifying anthropogenic emissions soon after the rush hour and before biogenic emissions are at their early afternoon peak.

Using a linear regression model to relate GEOS-Chem isoprene emissions to $\mathrm{HCHO}$ columns we inferred seasonal isoprene emissions over two key forest regions from the OMI HCHO column data. We found that the a posteriori emissions are typically lower than the a priori emissions, with a much stronger reduction of emissions during the monsoon season. This reduction in emissions during monsoon months coincided with a large drop in satellite observations of leaf phenology. Large-scale differences in observed and model HCHO columns during monsoon months may highlight errors in seasonal variations in basal emission rates and/or model errors associated with the underlying meteorological environments, e.g. partitioning of direct and diffuse photosynthetically active radiation.

The next logical step to this analysis is to estimate simultaneous estimates of anthropogenic, pyrogenic, and biogenic VOC emissions by using data collecting data from morning and afternoon local overpass times. In the case of biogenic VOC emissions, information from $\mathrm{HCHO}$ columns together with leaf phenology (e.g. leaf area index) and land surface parameters (e.g. soil moisture), can be integrated to develop a new satellite data-driven isoprene emission inventory. A self-consistent pan-tropical emission inventory for isoprene, for example, would help to improve understanding of tropospheric $\mathrm{O}_{3}$ and organic aerosol that represent some of the largest uncertainties associated with the Earth system. Our ability to achieve this capability is improved by the launch of TROPOMI aboard Sentinel-5P which will result in daily maps of HCHO columns and complementary trace gases at a spatial resolution of $7 \mathrm{~km}$, which dramatically increases the number of clear-sky scenes available for the analysis.

Data availability. The OMHCHOv003 OMI HCHO column data are publicly available through NASA's Mirador website. Model data are archived at the Edinburgh Data Share http://dx.doi.org/10.7488/ ds/2305 (Surl, 2018).

Author contributions. LS and PIP designed the computational experiments, PIP and LS wrote the paper, and GGA provided input on the paper regarding the OMI data analysis.

Competing interests. The authors declare that they have no conflict of interest.

Acknowledgements. Luke Surl was funded by the NERC National Centre for Earth Observation (NCEO020005), and Paul I. Palmer gratefully acknowledges his Royal Society Wolfson Research Merit Award. Luke Surl also acknowledges funding from the British Council Newton Fund (215829867), administered by the University of Birmingham. We are grateful to Kelly Chance from the Harvard-Smithsonian Center for Astrophysics, the Harvard University GEOS-Chem group, who maintains the model, and to Rolf Sander for maintaining the CAABA/MECCA box model.

Edited by: Robert McLaren

Reviewed by: two anonymous referees

\section{References}

Abbot, D. S., Palmer, P. I., Martin, R. V., Chance, K. V., Jacob, D. J., and Guenther, A.: Seasonal and interannual variability of North American isoprene emissions as determined by formaldehyde column measurements from space, Geophys. Res. Lett., 30, 1886, https://doi.org/10.1029/2003GL017336, 2003.

Barkley, M. P., Palmer, P. I., Kuhn, U., Kesselmeier, J., Chance, K., Kurosu, T. P., Martin, R. V., Helmig, D., and Guenther, A.: Net ecosystem fluxes of isoprene over tropical South America inferred from Global Ozone Monitoring Experiment (GOME) observations of HCHO columns, J. Geophys. Res.-Atmos., 113, d20304, https://doi.org/10.1029/2008JD009863, 2008.

Barkley, M. P., Palmer, P. I., De Smedt, I., Karl, T., Guenther, A., and Van Roozendael, M.: Regulated large-scale annual shutdown of Amazonian isoprene emissions?, Geophys. Res. Lett., 36, L04803, https://doi.org/10.1029/2008GL036843, 2009.

Barkley, M. P., De Smedt, I., Van Roozendael, M., Kurosu, T. P., Chance, K., Arneth, A., Hagberg, D., Guenther, A., Paulot, F., Marais, E., and Mao, J.: Top-down isoprene emissions over tropical South America inferred from SCIAMACHY and OMI 
formaldehyde columns, J. Geophys. Res.-Atmos., 118, 68496868, https://doi.org/10.1002/jgrd.50552, 2013.

Caldararu, S., Palmer, P. I., and Purves, D. W.: Inferring Amazon leaf demography from satellite observations of leaf area index, Biogeosciences, 9, 1389-1404, https://doi.org/10.5194/bg9-1389-2012, 2012.

Caldararu, S., Purves, D. W., and Palmer, P. I.: Phenology as a strategy for carbon optimality: a global model, Biogeosciences, 11, 763-778, https://doi.org/10.5194/bg-11-763-2014, 2014.

Carter, W.: Documentation of the SAPRC-99 Chemical Mechanism for VOC Reactivity Assessment, 2000.

Chance, K., Palmer, P. I., Spurr, R. J. D., Martin, R. V., Kurosu, T. P., and Jacob, D. J.: Satellite observations of formaldehyde over North America from GOME, Geophys. Res. Lett., 27, 34613464, https://doi.org/10.1029/2000GL011857, 2000.

Cohen, A. J., Brauer, M., Burnett, R., Anderson, H. R., Frostad, J., Estep, K., Balakrishnan, K., Brunekreef, B., Dandona, L., Dandona, R., Feigin, V., Freedman, G., Hubbell, B., Jobling, A., Kan, H., Knibbs, L., Liu, Y., Martin, R., Morawska, L., Pope, C. A., Shin, H., Straif, K., Shaddick, G., Thomas, M., van Dingenen, R., van Donkelaar, A., Vos, T., Murray, C. J. L., and Forouzanfar, M. H.: Estimates and 25-year trends of the global burden of disease attributable to ambient air pollution: an analysis of data from the Global Burden of Diseases Study 2015, The Lancet, 389, 1907-1918, https://doi.org/10.1016/S0140-6736(17)305056, 2017.

Curci, G., Palmer, P. I., Kurosu, T. P., Chance, K., and Visconti, G.: Estimating European volatile organic compound emissions using satellite observations of formaldehyde from the Ozone Monitoring Instrument, Atmos. Chem. Phys., 10, 11501-11517, https://doi.org/10.5194/acp-10-11501-2010, 2010.

De Smedt, I., Müller, J.-F., Stavrakou, T., van der A, R., Eskes, H., and Van Roozendael, M.: Twelve years of global observations of formaldehyde in the troposphere using GOME and SCIAMACHY sensors, Atmos. Chem. Phys., 8, 4947-4963, https://doi.org/10.5194/acp-8-4947-2008, 2008.

De Smedt, I., Stavrakou, T., Müller, J.-F., van der A, R. J., and Van Roozendael, M.: Trend detection in satellite observations of formaldehyde tropospheric columns, Geophys. Res. Lett., 37, 118808, https://doi.org/10.1029/2010GL044245, 2010.

De Smedt, I., Stavrakou, T., Hendrick, F., Danckaert, T., Vlemmix, T., Pinardi, G., Theys, N., Lerot, C., Gielen, C., Vigouroux, C., Hermans, C., Fayt, C., Veefkind, P., Müller, J.-F., and Van Roozendael, M.: Diurnal, seasonal and long-term variations of global formaldehyde columns inferred from combined OMI and GOME-2 observations, Atmos. Chem. Phys., 15, 12519-12545, https://doi.org/10.5194/acp-15-12519-2015, 2015.

Eastham, S. D., Weisenstein, D. K., and Barrett, S. R.: Development and evaluation of the unified troposphericstratospheric chemistry extension (UCX) for the global chemistry-transport model GEOS-Chem, Atmos. Environ., 89, 52-63, https://doi.org/10.1016/j.atmosenv.2014.02.001, 2014.

Friedl, M. A., Sulla-Menashe, D., Tan, B., Schneider, A., Ramankutty, N., Sibley, A., and Huang, X.: MODIS Collection 5 global land cover: Algorithm refinements and characterization of new datasets, Remote Sens. Environ., 114, 168-182, https://doi.org/10.1016/j.rse.2009.08.016, 2010.

Fu, T.-M., Jacob, D. J., Palmer, P. I., Chance, K., Wang, Y. X., Barletta, B., Blake, D. R., Stanton, J. C., and Pilling, M. J.: Space- based formaldehyde measurements as constraints on volatile organic compound emissions in east and south Asia and implications for ozone, J. Geophys. Res.-Atmos., 112, d06312, https://doi.org/10.1029/2006JD007853, 2007.

González Abad, G., Liu, X., Chance, K., Wang, H., Kurosu, T. P., and Suleiman, R.: Updated Smithsonian Astrophysical Observatory Ozone Monitoring Instrument (SAO OMI) formaldehyde retrieval, Atmos. Meas. Tech., 8, 19-32, https://doi.org/10.5194/amt-8-19-2015, 2015.

Gonzi, S., Palmer, P. I., Barkley, M. P., De Smedt, I., and Van Roozendael, M.: Biomass burning emission estimates inferred from satellite column measurements of HCHO: Sensitivity to co-emitted aerosol and injection height, Geophys. Res. Lett., 38, 114807, https://doi.org/10.1029/2011GL047890, 2011.

Guenther, A. B., Jiang, X., Heald, C. L., Sakulyanontvittaya, T., Duhl, T., Emmons, L. K., and Wang, X.: The Model of Emissions of Gases and Aerosols from Nature version 2.1 (MEGAN2.1): an extended and updated framework for modeling biogenic emissions, Geosci. Model Dev., 5, 1471-1492, https://doi.org/10.5194/gmd-5-1471-2012, 2012.

Jaeglé, L., Jacob, D. J., Wang, Y., Weinheimer, A. J., Ridley, B. A., Campos, T. L., Sachse, G. W., and Hagen, D. E.: Sources and chemistry of $\mathrm{NO}_{x}$ in the upper troposphere over the United States, Geophys. Res. Lett., 25, 1705-1708, https://doi.org/10.1029/97GL03591, 1998.

Justice, C., Giglio, L., Korontzi, S., Owens, J., Morisette, J., Roy, D., Descloitres, J., Alleaume, S., Petitcolin, F., and Kaufman, Y.: The MODIS fire products, Remote Sens. Environ., 83, 244-262, https://doi.org/10.1016/S0034-4257(02)00076-7, Special issue: Moderate Resolution Imaging Spectroradiometer (MODIS): a new generation of Land Surface Monitoring, 2002.

Kurokawa, J., Ohara, T., Morikawa, T., Hanayama, S., JanssensMaenhout, G., Fukui, T., Kawashima, K., and Akimoto, H.: Emissions of air pollutants and greenhouse gases over Asian regions during 2000-2008: Regional Emission inventory in ASia (REAS) version 2, Atmos. Chem. Phys., 13, 11019-11058, https://doi.org/10.5194/acp-13-11019-2013, 2013.

Levelt, P. F., van den Oord, G. H. J., Dobber, M. R., Mälkki, A., Visser, H., de Vries, J., Stammes, P., Lundell, J. O. V., and Saari, H.: The Ozone Monitoring Instrument, IEEE T. Geosci. Remote, 44, 1093-1101, 2006.

Li, M., Zhang, Q., Kurokawa, J.-I., Woo, J.-H., He, K., Lu, Z., Ohara, T., Song, Y., Streets, D. G., Carmichael, G. R., Cheng, Y., Hong, C., Huo, H., Jiang, X., Kang, S., Liu, F., Su, H., and Zheng, B.: MIX: a mosaic Asian anthropogenic emission inventory under the international collaboration framework of the MICS-Asia and HTAP, Atmos. Chem. Phys., 17, 935-963, https://doi.org/10.5194/acp-17-935-2017, 2017.

Lin, Y. C., Schwab, J. J., Demerjian, K. L., Bae, M.-S., Chen, W.N., Sun, Y., Zhang, Q., Hung, H.-M., and Perry, J.: Summertime formaldehyde observations in New York City: Ambient levels, sources and its contribution to HOx radicals, J. Geophys. Res.Atmos., 117, d08305, https://doi.org/10.1029/2011JD016504, 2012.

Lu, Z. and Streets, D. G.: Increase in NOx Emissions from Indian Thermal Power Plants during 1996-2010: Unit-Based Inventories and Multisatellite Observations, Environ. Sci. Technol., 46, 7463-7470, https://doi.org/10.1021/es300831w, 2012. 
Lu, Z., Zhang, Q., and Streets, D. G.: Sulfur dioxide and primary carbonaceous aerosol emissions in China and India, 1996-2010, Atmos. Chem. Phys., 11, 9839-9864, https://doi.org/10.5194/acp-11-9839-2011, 2011.

Mahajan, A. S., Smedt, I. D., Biswas, M. S., Ghude, S., Fadnavis, S., Roy, C., and van Roozendael, M.: Inter-annual variations in satellite observations of nitrogen dioxide and formaldehyde over India, Atmos. Environ., 116, 194-201, https://doi.org/10.1016/j.atmosenv.2015.06.004, 2015.

Marais, E. A., Jacob, D. J., Kurosu, T. P., Chance, K., Murphy, J. G., Reeves, C., Mills, G., Casadio, S., Millet, D. B., Barkley, M. P., Paulot, F., and Mao, J.: Isoprene emissions in Africa inferred from OMI observations of formaldehyde columns, Atmos. Chem. Phys., 12, 6219-6235, https://doi.org/10.5194/acp12-6219-2012, 2012

Martin, R. V., Jacob, D. J., Chance, K., Kurosu, T. P., Palmer, P. I., and Evans, M. J.: Global inventory of nitrogen oxide emissions constrained by space-based observations of NO2 columns, J. Geophys. Res.-Atmos., 108, 4537, https://doi.org/10.1029/2003JD003453, 2003.

Marvin, M. R., Wolfe, G. M., Salawitch, R. J., Canty, T. P., Roberts, S. J., Travis, K. R., Aikin, K. C., de Gouw, J. A., Graus, M., Hanisco, T. F., Holloway, J. S., Hübler, G., Kaiser, J., Keutsch, F. N., Peischl, J., Pollack, I. B., Roberts, J. M., Ryerson, T. B., Veres, P. R., and Warneke, C.: Impact of evolving isoprene mechanisms on simulated formaldehyde: An inter-comparison supported by in situ observations from SENEX, Atmos. Environ., 164, 325-336, https://doi.org/10.1016/j.atmosenv.2017.05.049, 2017.

Millet, D. B., Jacob, D. J., Boersma, K. F., Fu, T.-M., Kurosu, T. P., Chance, K., Heald, C. L., and Guenther, A.: Spatial distribution of isoprene emissions from North America derived from formaldehyde column measurements by the OMI satellite sensor, J. Geophys. Res.-Atmos., 113, d02307, https://doi.org/10.1029/2007JD008950, 2008.

Pai, D. S. and Bhan, S. C.: Monsoon 2014 A Report, Tech. Rep. ESSO/IMD/Synoptic Met./01(2015)/17, India Meteorological Department, 2015.

Palmer, P. I., Jacob, D. J., Chance, K., Martin, R. V., Spurr, R. J. D., Kurosu, T. P., Bey, I., Yantosca, R., Fiore, A., and Li, Q.: Air mass factor formulation for spectroscopic measurements from satellites: Application to formaldehyde retrievals from the Global Ozone Monitoring Experiment, J. Geophys. Res.-Atmos., 106, 14539-14550, https://doi.org/10.1029/2000JD900772, 2001.

Palmer, P. I., Jacob, D. J., Fiore, A. M., Martin, R. V., Chance, K., and Kurosu, T. P.: Mapping isoprene emissions over North America using formaldehyde column observations from space, J. Geophys. Res.-Atmos., 108, 4180, https://doi.org/10.1029/2002JD002153, 2003.

Palmer, P. I., Abbot, D. S., Fu, T.-M., Jacob, D. J., Chance, K., Kurosu, T. P., Guenther, A., Wiedinmyer, C., Stanton, J. C., Pilling, M. J., Pressley, S. N., Lamb, B., and Sumner, A. L.: Quantifying the seasonal and interannual variability of North American isoprene emissions using satellite observations of the formaldehyde column, J. Geophys. Res.-Atmos., 111, D12315, https://doi.org/10.1029/2005JD006689, 2006.

Palmer, P. I., Barkley, M. P., Kurosu, T. P., Lewis, A. C., Saxton, J. E., Chance, K., and Gatti, L. V.: Interpreting satellite column observations of formaldehyde over tropi- cal South America, Philos. T. R. Soc. A, 365, 1741-1751, https://doi.org/10.1098/rsta.2007.2042, 2007.

Perianayagam, A. and Goli, S.: Provisional results of the 2011 Census of India: Slowdown in growth, ascent in literacy, but more missing girls, Int. J. Soc. Econ., 39, 785-801, https://doi.org/10.1108/03068291211253395, 2012.

Sander, R., Baumgaertner, A., Gromov, S., Harder, H., Jöckel, P., Kerkweg, A., Kubistin, D., Regelin, E., Riede, H., Sandu, A., Taraborrelli, D., Tost, H., and Xie, Z.-Q.: The atmospheric chemistry box model CAABA/MECCA-3.0, Geosci. Model Dev., 4, 373-380, https://doi.org/10.5194/gmd-4-373-2011, 2011.

Sander, R., Jöckel, P., Kirner, O., Kunert, A. T., Landgraf, J., and Pozzer, A.: The photolysis module JVAL-14, compatible with the MESSy standard, and the JVal PreProcessor (JVPP), Geosci. Model Dev., 7, 2653-2662, https://doi.org/10.5194/gmd-7-26532014, 2014.

Santenda and Kaushik, A. D.: Forest Fire Disaster Management, Tech. rep., Institute of Disaster Management, Ministry of Home Affairs, New Delhi, ISBN: 978-93-82571-09-4, 2014.

Sharma, S., Chatani, S., Mahtta, R., Goel, A., and Kumar, A.: Sensitivity analysis of ground level ozone in India using WRF-CMAQ models, Atmos. Environ., 131, 29-40, https://doi.org/10.1016/j.atmosenv.2016.01.036, 2016.

Shim, C., Wang, Y., Choi, Y., Palmer, P. I., Abbot, D. S., and Chance, K.: Constraining global isoprene emissions with Global Ozone Monitoring Experiment (GOME) formaldehyde column measurements, J. Geophys. Res.-Atmos., 110, d24301, https://doi.org/10.1029/2004JD005629, 2005.

Singaas, E. L., Lerdau, M., Winter, K., and Sharkey, T. D.: Isoprene increases thermotolerance of isopreneemitting species, Plant Physiol., 115, 1413-1420, https://doi.org/10.1104/pp.115.4.1413, 1997.

Stavrakou, T., Müller, J.-F., De Smedt, I., Van Roozendael, M., van der Werf, G. R., Giglio, L., and Guenther, A.: Global emissions of non-methane hydrocarbons deduced from SCIAMACHY formaldehyde columns through 2003-2006, Atmos. Chem. Phys., 9, 3663-3679, https://doi.org/10.5194/acp-9-36632009, 2009.

Stavrakou, T., Müller, J.-F., Bauwens, M., De Smedt, I., Lerot, C., Van Roozendael, M., Clerbaux, C., Boersma, K. F., van der A, R., and Song, Y.: Substantial Underestimation of Post-Harvest Burning Emissions in the North China Plain Revealed by MultiSpecies Space Observations, Nature Scientific Reports, 6, 32307, https://doi.org/10.1038/srep32307, 2016.

Surl, L.: Model output relating to $\mathrm{HCHO}$ columns over India, 2014 [dataset], University of Edinburgh, School of Geosciences, https://doi.org/10.7488/ds/2305, 2018.

Taraborrelli, D., Lawrence, M. G., Butler, T. M., Sander, R., and Lelieveld, J.: Mainz Isoprene Mechanism 2 (MIM2): an isoprene oxidation mechanism for regional and global atmospheric modelling, Atmos. Chem. Phys., 9, 2751-2777, https://doi.org/10.5194/acp-9-2751-2009, 2009.

Thomas, W., Hegels, E., Slijkhuis, S., Spurr, R., and Chance, K.: Detection of biomass burning combustion products in Southeast Asia from backscatter data taken by the GOME Spectrometer, Geophys. Res. Lett., 25, 1317-1320, https://doi.org/10.1029/98GL01087, 1998.

Tyagi, S., Tiwari, S., Mishra, A., Hopke, P. K., Attri, S., Srivastava, A., and Bisht, D.: Spatial variability of concen- 
trations of gaseous pollutants across the National Capital Region of Delhi, India, Atmos. Pollut. Res., 7, 808-816, https://doi.org/10.1016/j.apr.2016.04.008, 2016.

van der Werf, G. R., Randerson, J. T., Giglio, L., van Leeuwen, T. T., Chen, Y., Rogers, B. M., Mu, M., van Marle, M. J. E., Morton, D. C., Collatz, G. J., Yokelson, R. J., and Kasibhatla, P. S.: Global fire emissions estimates during 1997-2016, Earth Syst. Sci. Data, 9, 697-720, https://doi.org/10.5194/essd-9-697-2017, 2017.

Volkamer, R., Sheehy, P., Molina, L. T., and Molina, M. J.: Oxidative capacity of the Mexico City atmosphere - Part 1: A radical source perspective, Atmos. Chem. Phys., 10, 6969-6991, https://doi.org/10.5194/acp-10-6969-2010, 2010.

Wang, C., Huang, X.-F., Han, Y., Zhu, B., and He, L.-Y.: Sources and Potential Photochemical Roles of Formaldehyde in an Urban Atmosphere in South China, J. Geophys. Res.-Atmos., 122, 11934-11947, https://doi.org/10.1002/2017JD027266, 2017.

Whalley, L. K., Furneaux, K. L., Goddard, A., Lee, J. D., Mahajan, A., Oetjen, H., Read, K. A., Kaaden, N., Carpenter, L. J., Lewis, A. C., Plane, J. M. C., Saltzman, E. S., Wiedensohler, A., and Heard, D. E.: The chemistry of $\mathrm{OH}$ and $\mathrm{HO}_{2}$ radicals in the boundary layer over the tropical Atlantic Ocean, Atmos. Chem. Phys., 10, 1555-1576, https://doi.org/10.5194/acp10-1555-2010, 2010.

Wolfe, G. M., Kaiser, J., Hanisco, T. F., Keutsch, F. N., de Gouw, J. A., Gilman, J. B., Graus, M., Hatch, C. D., Holloway, J., Horowitz, L. W., Lee, B. H., Lerner, B. M., LopezHilifiker, F., Mao, J., Marvin, M. R., Peischl, J., Pollack, I. B., Roberts, J. M., Ryerson, T. B., Thornton, J. A., Veres, P. R., and Warneke, C.: Formaldehyde production from isoprene oxidation across $\mathrm{NO}_{x}$ regimes, Atmos. Chem. Phys., 16, 2597-2610, https://doi.org/10.5194/acp-16-2597-2016, 2016.
Young, E. L. and Paton-Walsh, C.: Formaldehyde and nitrogen dioxide in smoke plumes from Australia's Black Saturday fires, IOP Conference Series: Earth and Environmental Science, 11, 012023, http://stacks.iop.org/1755-1315/11/i=1/a= 012023, 2010.

Zhu, L., Jacob, D. J., Mickley, L. J., Marais, E. A., Cohan, D. S., Yoshida, Y., Duncan, B. N., Abad, G. G., and Chance, K. V.: Anthropogenic emissions of highly reactive volatile organic compounds in eastern Texas inferred from oversampling of satellite (OMI) measurements of HCHO columns, Environ. Res. Lett., 9, 114004, https://doi.org/10.1088/1748-9326/9/11/114004, 2014.

Zhu, L., Jacob, D. J., Kim, P. S., Fisher, J. A., Yu, K., Travis, K. R., Mickley, L. J., Yantosca, R. M., Sulprizio, M. P., De Smedt, I., González Abad, G., Chance, K., Li, C., Ferrare, R., Fried, A., Hair, J. W., Hanisco, T. F., Richter, D., Jo Scarino, A., Walega, J., Weibring, P., and Wolfe, G. M.: Observing atmospheric formaldehyde ( $\mathrm{HCHO})$ from space: validation and intercomparison of six retrievals from four satellites (OMI, GOME2A, GOME2B, OMPS) with SEAC ${ }^{4} \mathrm{RS}$ aircraft observations over the southeast US, Atmos. Chem. Phys., 16, 1347713490, https://doi.org/10.5194/acp-16-13477-2016, 2016. 